derheit kontrolliert worden zu sein, ähnlich wie es bei vielen anderen Aktivitäten in dieser Periode der Fall war. Die Kollaboration wurde von der Minderheitenorganisation DBN organisiert und kontrolliert. Die DBN war das Bindeglied zwischen der Besatzungsmacht und den kleinen Handwerksmeistern, die die Mehrheit der finanziellen Kollaborateure innerhalb der Minderheit ausmachten.

Das Ausmaß der Kollaboration scheint groß gewesen zu sein, nicht nur weil es von der Minderheit organisiert wurde, sondern auch weil die Quellenunterlagen nachweisen, dass der Umsatz und der Gewinn eine sehr große Spannweite hatten.

Die Unterlagen machen es ebenfalls deutlich, dass die Kollaborateure vor allem Männer aus der Minderheit mittleren Alters waren. Die Tendenzen innerhalb der finanziellen Kollaboration der Minderheit weist Unterschiede auf im Vergleich zu den generellen Tendenzen der finanziellen Kollaborateure in Dänemark. Meine Auffassung ist es, dass dies im Zusammenhang mit dem Wunsch der Minderheit nach einer Grenzberichtigung gesehen werden muss. Jede Gruppierung der Minderheit hat deshalb das geleistet, was für sie möglich war, und da die Gruppe von Männern mittleren Alters nicht wie die jüngeren Männer die Möglichkeit hatte, sich freiwillig an die Front zu melden, haben sie ihr Opfer für das Vaterland in der finanziellen Kollaboration geleistet.

\section{"Spadeslaget" i Haderslev den 8. december 1940}

Af Hans Schultz Hansen

Den 8. december 1940 afholdt Danmarks National-Socialistiske Arbejder-Parti et offentligt møde på Højskolehjemmet i Haderslev. Forud for mødet gik DNSAP's sønderjyske Sports-Afdeling i uniform og med spader i demonstrationsmarch gennem byens gader. Derved overtrådte SA forbuddet mod politisk uniformering. Politiet var for fåtalligt til at hindre marchen, men efter at have hentet forstærkning omringede politiet Højskolehjemmet. SA'erne lod sig ikke frivilligt arrestere og brugte deres spader mod politiet, der til gengæld satte ind med tåregas og brandsprøjter. Sammenstødet fik siden betegnelsen Spadeslaget. Hans Schultz Hansen redegør her for Spadeslagets forløb.

Da de danske nazister greb ud efter magten

Med den tyske besættelse af Danmark den 9. april 1940 blev en nazistisk regering en mulighed. Frits Clausen og hans følge i DNSAP ønskede og efterstræbte den. Samlingsregeringen og de demokratiske partier i Rigsdagen frygtede og modarbejdede den. I dette spil var tyskerne den afgørende faktor, da DNSAP var for svagt til selv at erobre regeringsmagten. Kun ved en stærk tysk pression mod konge, regering og rigsdag kunne dette ske.

DNSAP's forsøg på at vinde besættelsesmagten for en nazistisk regering er grundigt belyst af besættelsestidshistorikeren Henning Poulsen. ${ }^{1}$ Han har påvist, at tyskernes lydhørhed over for DNSAP voksede efter den tyske sejr over Frankrig i juni 1940. Fra august finansierede de DNSAP's propagandaoffensiv for indsættelse af Frits Clausen som statsminister. Det var nu op til partiet selv at vokse sig stort og stærkt. Et øjeblikkeligt regeringsskifte var tyskerne ikke indstillet på. I den sidste del af september synes Hitler imidlertid at have sat sig for at skabe et storgermansk rige. Indsættelse af nazistiske regeringer i de besatte lande blev set som et første skridt til at nå dette mål. Også et regeringsskifte i Danmark blev overvejet. Den tyske gesandt i København, Cecil von Renthe-Fink, foretrak at fortsætte samarbejdet med den siddende Stauning-regering. Truslen fra et styrket DNSAP kunne imidlertid bruges til at presse den danske regering, og han øgede derfor støtten til de 
danske nazister. I begyndelsen af oktober gik han et skridt videre og spurgte udenrigsminister Joachim von Ribbentrop om en beslutning i regeringsspørgsmålet. Midt i november besluttede Ribbentrop ikke at gå efter et dansk regeringsskifte, og i december gav han Renthe-Fink besked på, at denne nok måtte videreføre støtten til DNSAP, men ikke risikere en konflikt med Christian 10. Nu optog det kommende angreb på Sovjetunionen Hitler helt, og storgermanske planer blev udsat til efter krigen.

På dette bagtæppe af håb om og frygt for en nazistisk regeringsovertagelse i Danmark iværksatte DNSAP i andet halvår af 1940 flere demonstrationer. De er indgående analyseret af retshistorikeren Henning Koch. ${ }^{2}$ De brød med et forbud mod offentlige møder, optog og demonstrationer, som var udstedt efter den 9. april, og med et forbud mod politisk uniformering fra 1933, der senest var blevet fornyet i foråret $1940 .^{3}$

Lov om forbud mod at bære uniform m.v. fastslog i sin første paragraf: "Det er forbudt at bære uniform eller beklædningsgenstande, der kan sidestilles hermed. Ligeledes er det forbudt at bære uniformsdele, armbind eller andre iøjnefaldende tegn, der viser, at bæreren tilhører en politisk organisation. Justitsministeren kan meddele dispensation fra forbuddet." Hæren og flåden, de statslige og kommunale funktionærer, uniformerede ansatte i private erhverv, kostskoleelever, spejdere, sportsudøvere under 16 år og deres ledere var undtaget fra forbuddet. ${ }^{4}$ Søndag den 30. juni 1940 gennemførte DNSAP et offentligt møde på Højskolehjemmet i Roskilde med efterfølgende demonstrationsmarch. Mens Roskilde politi affandt sig med det ulovlige offentlige møde, kaldte det forstærkninger til for at forhindre marchen. Med i marchen gik et halvt hundrede tyske soldater, som deltog i slagsmålet med politiet under marchen og i Højskolehjemmets gård, sidste sted med bajonetterne fremme. Politiet måtte derfor trække sig tilbage. Først med en tysk officers mellemkomst blev uroen standset. Det var ikke en god dag for politiet. Efter forhandlinger om mandagen forbød den tyske øverstbefalende sine soldater at deltage i møder og demonstrationer arrangeret af danske politiske partier. Den stedlige politimester skulle herefter forud for DNSAP-arrangementer underrette den lokale tyske garnisonskommandant, så denne kunne holde de tyske soldater på kasernen. ${ }^{5}$

Allerede den 2. juli 1940 forsøgte DNSAP at følge op på den tilsyneladende sejr i Roskilde ved en demonstration i København, hvor cyklister ad Lyngbyvejen skulle søge mod centrum. Så langt kom de ikke. Denne gang var politiet på plads, og ca. 150 nazister blev anholdt og siden idømt hæftestraffe. Tyske soldater så man ikke skyggen af. Provokationerne blev foreløbigt indstillet. ${ }^{6}$

Den 16. oktober 1940 udkom Bekendtgørelse om afholdelse af offentlige møder. Indendørs møder kunne herefter afholdes uden særlig tilladelse, men de skulle anmeldes til politiet senest tre dage forud. Bekendtgørelsen fastslog derimod: "De udstedte forbud mod møder under åben himmel, mod offentlige optog og demonstrationer af enhver art og mod enhver form for sammenstimlen forbliver i kraft".?

I november 1940 ændrede DNSAP's propaganda retning. Nederlaget og de faldne den 9. april blev instrumentaliseret i et hårdt angreb på regeringen med trusler om "afsløringer", der ville føre til dens fald. Den 17. november gik DNSAP med dispensation fra politiet i march fra Københavns Forum til Rådhuspladsen, hvor der blev afholdt en mindeappel for de døde den 9. april ved statuen af "Den lille hornblæser", som var rejst til minde om de faldne i de slesvigske krige. Politiets største udfordring var denne gang at holde de københavnere på afstand, som var harmfulde over DNSAP's forsøg på at forpagte nationens døde. Da nazisterne efter den mislykkede højtidelighed gik hver til sit, fik mange af dem bank. Kampagnen blev en fiasko. ${ }^{8}$

Den næste demonstrationsmarch fandt sted den 8. december $1940 \mathrm{i}$ Haderslev. DNSAP indkaldte helt efter reglerne til et offentligt møde på Højskolehjemmet. Men forud for dette marcherede SA i uniform og med spader gennem byen, hvilket stadig var ulovligt. Det endte i en hård konfrontation med politiet. Henning Poulsen formoder, at Frits Clausen stod bag mødet og marchen og skriver: "Haderslevslaget lader sig uden vanskelighed opfatte som partiførerens sidste forsøg på at fremprovokere en krise, der på ny kunne rejse regeringsspørgsmålet". Sikkert er det i hvert fald, at Frits Clausen i november havde kritiseret SA's stabschef Axel Juul for SA's passivitet, og at Jes Friis som leder af det sønderjyske SA omvendt var blandt de mest aktivistiske SA-ledere. ${ }^{9}$

Selve "Spadeslaget" omtales kun i hovedtræk af Henning Poulsen. ${ }^{10}$ Henning Koch er den første, der har beskæftiget sig indgående med begivenheden med hovedvægten på politiets rolle. ${ }^{11}$ I den landsdel, hvor Spadeslaget fandt sted, vil der formentlig være interesse for en yderligere udbygget undersøgelse, og det så meget mere, som Haderslev politis omfattende materiale om Spadeslaget nu 75 år efter begivenheden er blevet frit tilgængeligt.

Hensigten med denne artikel er at rekonstruere Spadeslagets forløb i dets tre vigtigste faser: SA's demonstrationsmarch, det offentlige møde 
Jes Jensen Friis (1911-1987) fra Øster Løgum var i 1940 fylkefører for det sønderjyske $S A$. Som sådan gik han $i$ spidsen for den ulovlige march med spader igennem Haderslev, ligesom han havde kommandoen over SA'erne under slagsmåle med politiet på Højskolehjemmet. Foto: Rigsarkivet Aabenraa, Haderslev politi nr. 909.

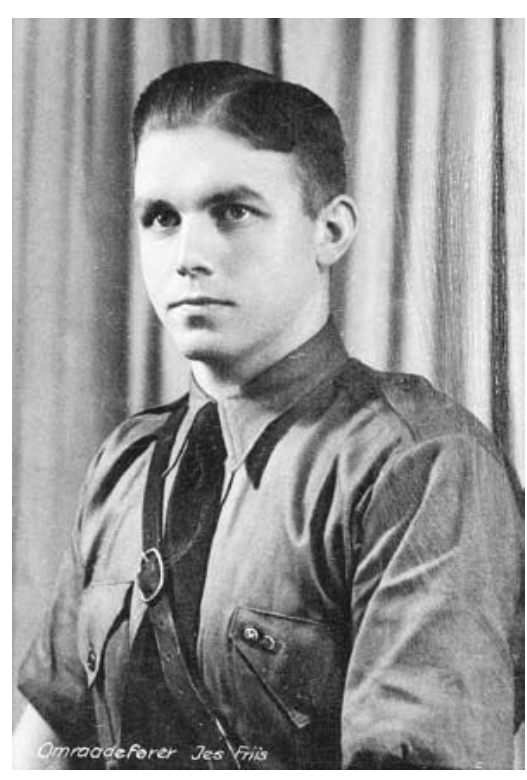

med tilhørende slagsmål mellem SA og politiet samt politiets afsluttende masseanholdelsesaktion. Fokus vil her navnlig være på optakten til marchen, de stridende parters styrker og styrkeopbygning, deres bevæbning, nazisternes lovovertrædelser og politiets reaktion. Tre spørgsmål skal specielt søges besvaret: Hvem tog initiativet til marchen, hvad var dens formål, og stod politiets magtmidler og magtanvendelse i et rimeligt forhold til truslen fra SA? Derudover vil artiklen behandle to efterspil: Uroligheder i forbindelse med de anholdte SA-mænds løsladelse den 9. december og spillet mellem regeringen og besættelsesmagten om en amnesti til de anholdte.

\section{Kilderne til Spadeslaget}

Spadeslagets forløb fremgår af Haderslev politis rapporter. Politiassistent C. J. Toft skrev en rapport på selve dagen. Den indgik som bilag til politimester Frantz Hartmanns hovedrapport af 28. december 1940. Begge rapporter beskriver det samlede forløb. Der er på det nærmeste fuld enighed mellem de to rapportskrivere. Det må formodes, at Hartmann foruden sin egen hukommelse har bygget sin fremstilling på Tofts rapport. Denne undersøgelse beror hovedsagelig på disse to rapporter, som der hermed henvises til én gang for alle. Andre rapporter dækker enkelte faser af slaget eller er senere, men også her er der en vidtgående overensstemmelse. Hvor disse og andre kilder inddrages, henvises der til dem.

I Politiadjudanten for de sønderjyske landsdeles arkiv findes en kort rapport af politimester Aage Agersted, Aabenraa, af 11. december om tilkald af forstærkninger samt en fjernskrivermeddelelse fra kriminalassistent Jacobsen til rigspolitichefen, dateret Haderslev den 8. december kl. 23. Politiadjudant var amtmand Kresten Refslund Thomsen i Aabenraa, der var overordnet koordinator for politiindsatsen i de sønderjyske politikredse, når det gjaldt opgaver med politisk betydning.

I Udenrigsministeriets arkiv ligger akterne om forhandlinger med besættelsesmagten om amnesti til deltagerne i Spadeslaget.

DNSAP's hovedorgan Fædrelandet bragte flere avisomtaler af Spadeslaget. De er stærkt præget af agitationen og må som kilder til slagets gang stå tilbage for politiets materiale.

\section{Styrkeforhold - organisation - bevæbning}

Sønderjylland var fra begyndelsen en højborg for DNSAP. Ved folketingsvalget $\mathrm{i}$ april 1939 fik partiet $4,7 \%$ af stemmerne i landsdelen mod 1,8 \% på landsplan. Partiføreren Frits Clausen var sønderjyde og praktiserende læge i Bovrup, hvor partihovedkontoret også fandtes. ${ }^{12}$ Der var således gode grunde til at gennemføre en demonstration i grænselandet.

DNSAP var som parti i alt væsentligt en efterligning af Adolf Hitlers National-Sozialistische Deutsche Arbeiter-Partei. Det gjaldt også organisatorisk. Som NSDAP bestod DNSAP af to grene. Ved siden af det civile politiske parti fandtes et uniformeret korps under forkortelsen SA. I Tyskland stod den for Sturm-Abteilung, i Danmark for Sports-Afdeling, fra juni 1941 for Storm-Afdeling. SA var begge steder beregnet for aktivistiske unge mænd, som var fyldt 18 år og indstillet på fysisk konfrontation med de politiske modstandere.

I Danmark var SA fra 1936 ligesom DNSAP organiseret efter den middelalderlige inddeling i sysler. ${ }^{13}$ Sønderjylland bestod af Ellum og Barvid Syssel, og sysselleder for DNSAP var her i årene 1938-43 smedemester Jes Asmussen fra Fogderup. Inden for SA udgjorde Ellum og Barvid Syssel "Område 1" med maskinbygger Jes Jensen Friis fra Øster Løgum (1911-1987) som områdefører, fra den 1. september 1940 med titel som fylkefører. Områderne i SA var yderligere underinddelt i ko- 
lonner, storme, grupper og sektioner. Det sønderjyske SA bestod af tre kolonner: 1. kolonne under Otto Schmidt, Tinglev Mølle, 2. kolonne under Laust Andersen, Skast, og 3. kolonne under Peter Jessen, Frørup. De tre kolonner bestod tilsammen af 18 storme. ${ }^{14}$ Tilsammen udgjorde styrken ifølge Jes Friis 200-250 mand, hvilket stemmer godt med, at der blev anholdt 239 i forbindelse med Spadeslaget. ${ }^{15}$

Dansk politi blev stærkt udvidet under besættelsen. Regeringen ville have en væbnet magt til at sætte ind mod indre uroligheder, herunder optøjer og kupforsøg fra DNSAP. I juli 1940 fik rigspolitichefen bemyndigelse til at ansætte 1.100 betjente på honorarbasis, altså ikke som tjenestemænd med varig ansættelse. Der blev bl.a. formeret 13 udrykningsdelinger med 25 betjente i hver, hvoraf to delinger tilfaldt Sønderjylland, den ene centralt placeret i Aabenraa, den anden fordelt ud over de andre fem sønderjyske politikredse. ${ }^{16}$

Haderslev politikreds dækkede den østlige halvdel af Haderslev amt. Politimester her var i årene 1935-56 Frantz Hartmann (1886-1962). Den 9. april 1940 havde han vist sig handlekraftig, da den lokale mobilisering blev sat i værk, og siden da kampen på Gammelting skulle standses. Haderslev politi var ikke nogen stor station. Den lokale styrke var på ca. 30 mand. ${ }^{17}$ Men Hartmann kunne trække på forstærkninger, og det gjorde han. På sit højeste bestod politistyrken af 130 ordensbetjente og nogle kriminalbetjente. ${ }^{18}$

SA'erne var bevæbnet med spader. Nogle bar en lang spade på 113 $\mathrm{cm}$, andre en kort på $47 \mathrm{~cm} \cdot{ }^{19}$ Efter slaget blev der beslaglagt 106 lange og 20 korte spader. Bladenes kanter var rundslebne, ikke skarptslebne. Endvidere blev en jernpind, en træstok og en del cykelpumper beslaglagt. ${ }^{20}$ Fra juni 1941 kendes et spadeeksercitsreglement for DNSAP, trykt i Tønder. Heri hed det: "Det har altid gennem tiderne været frimænds ret at bære våben, en ret som i øjeblikket er taget fra os. Denne ret agter vi nationalsocialister atter at indføre, og begyndelsen er gjort, idet vi foreløbig anvender spader; derfor må enhver S.A.-mand behandle sin spade som sit personlige våben, som det er en ære at bære, men som samtidig forpligter. En S.A.-mands spade må altid være blankpudset og indsmurt i olie. Ved at betragte S.A.-mandens våben, får man et indblik i hans karakter som politisk soldat". ${ }^{21}$

Enkelte SA-mænd medbragte på eget initiativ revolvere. I hvert fald blev der formiddagen efter slaget fundet en Mauser $7.65 \mathrm{~mm}$ pistol på Højskolehjemmet med en skarp patron i kammeret og syv i magasinet. Den 30. december $1940 \mathrm{blev}$ der fremdraget en Walther $7.65 \mathrm{~mm}$ revolver med otte patroner i magasinet. Den var sammen med en dolk gravet ned tæt ved Højskolehjemmets hovedindgang. ${ }^{22}$

Politiet var bevæbnet med stav og tjenestepistol. Politistaven var 51 cm lang og således kortere end SA'ernes lange spader. ${ }^{23}$ Til gengæld rådede alle faste polititjenestemænd siden oktober 1940 over en Browning 7.65 mm pistol; også honorarlønnede betjente kunne få udleveret pistoler. ${ }^{24}$ Udover disse enkeltmandsvåben rådede politiet over tåregasgranater. For både pistoler og tåregas gjaldt ifølge rigspolitichefens instruks fra oktober 1940: "Der må ikke benyttes skydevåben eller gas, medmindre det drejer sig om nødværge". ${ }^{25}$

\section{Demonstrationsmarchen ind mod byen}

- politiet underrettes

Haderslev politi var forud underrettet om, at DNSAP i Ellum og Barved Syssel agtede at afholde et "stort offentligt møde" på Højskolehjemmet søndag den 8. december kl. 16 med kaptajn Erik Lærum og den sjællandske sysselleder, købmand Ejnar Jørgensen som talere. Partiet spurgte den 29. november, om offentlige møder var lovlige, og den 5. december anmeldtes mødet til politiet, ligesom der den 6 . blev indsat en annonce for mødet i det nazistiske blad Fædrelandet. Den var undertegnet "Syssellederen", dvs. af Jes Asmussen. Haderslev politi gjorde ikke indvendinger mod mødet, der var lovligt varslet, men politimesteren gav ordre til, at styrken skulle være samlet på stationen fra kl. 15.30. Dog skulle en betjent posteres tæt på Højskolehjemmet fra kl. $14 \mathrm{og}$ to fra kl. 15, ligesom kriminaloverbetjent Riis og kriminalbetjent Mathiesen i civil skulle overvåge mødet i selve salen. ${ }^{26}$

Politiet var ikke vidende om den planlagte demonstrationsmarch. Det var SA'erne derimod gennem fylkefører Jes Friis' "områdebefaling nr. 18" af 30. november 1940. Her hed det i klartekst: "Søndag d. 8. decbr. stiller alle S.A. fra område 1 i Haderslev, hvor der K1. 16,- på Højskolehjemmet afholdes et stort offentlig møde med Kaptajn Lærum som taler. Bovrup S.A. orkester musicerer". Derpå hed det med en talkode, som det efterfølgende lykkedes politiet at afkode: "Kl. halv tre stiller alle to km syd for Haderslev, spader og tornystre medbringes". Endvidere blev der efter slaget fundet en iturevet og derfor vanskeligt læselig "kolonnebefaling nr. 1" for 4. kolonne under Sydjysk Fylking, underskrevet af kolonnefører Otto Schmidt. Den meddeler formentlig det samme som områdebefalingen. ${ }^{27}$ 
Jes Friis oplyste under afhøringerne: "Han har forud drøftet forholdene om selve mødet med sysselleder Jes Asmussen, Fogderup, men demonstrationsmarchen er hans egen beslutning, og han har alene ansvaret for denne". ${ }^{28}$ Asmussen angav tilsvarende: "I denne egenskab [som sysselleder] har han ansøgt om tilladelse til at afholde et offentligt

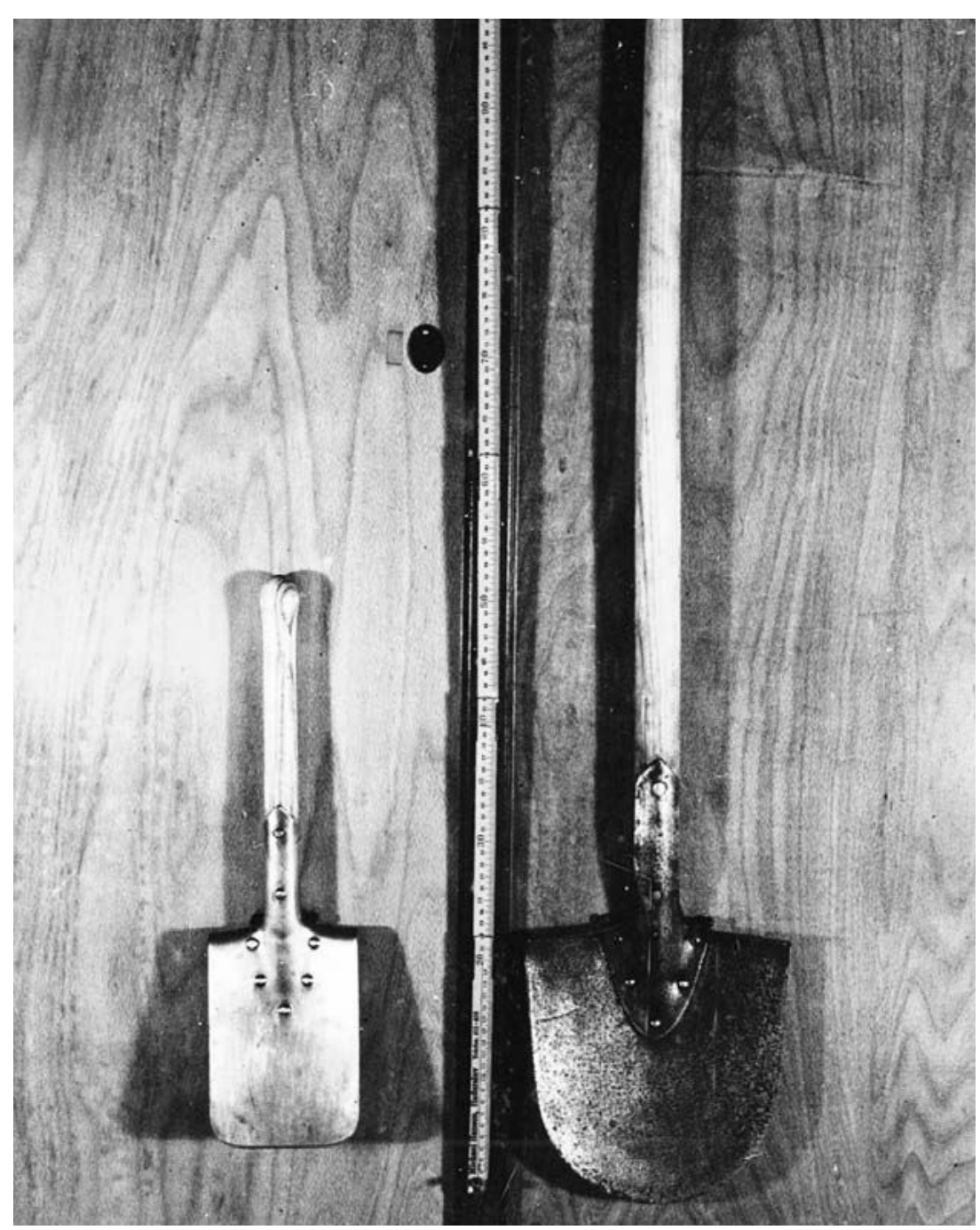

SA'erne var bevæbnet med spader - den korte spade på $47 \mathrm{~cm}$ eller den lange på 113 cm. Politiets stav var 51 cm lang. Foto: Rigsarkivet Aabenraa, Haderslev politi nr. 909. møde i Højskolehjemmet i Haderslev i dag den 8-12-1940 kl. 16. Det var partiet, som afholdt mødet. Anholdte har ikke haft nogen andel i den af partiets S.A. (Sports Afdeling) foretagen demonstrationsmarch gennem byen". ${ }^{29}$ Det må formodes, at rollefordelingen mellem de to ledere har været som angivet af dem begge. Dermed er det ikke udelukket, at Frits Clausen var den egentlige ophavsmand såvel til det offentlige møde som til demonstrationsmarchen, selv om der ikke er fundet beviser herpå i det benyttede kildemateriale. I det mindste er det sandsynligt, at han forud var informeret om og havde billiget begge dele. Med den blæst, der havde stået om de forudgående DNSAP-manifestationer, er det svært at tænke sig andet $i$ et autoritært opbygget parti. ${ }^{30}$ Ved at tie herom gjorde Asmussen og Friis i så fald deres til, at partiføreren ikke blev forbundet med den fiasko, som Spadeslaget blev for DNSAP.

SA'erne mødtes i henhold til områdebefalingen kl. 14.30 på Hovedvej 10 ved Revkjær Skov ca. 2 km syd for Haderslev. Overtøj, cykler m.m. blev opbevaret hos en husmand i nærheden. Demonstrationstoget blev formeret med fylkefører Jes Friis i spidsen fulgt af ca. 25 SA'ere med korte spader og stålhjelme. Så kom musikken, og derefter kolonnefører Otto Schmidt fra Tinglev med ca. 120 SA'ere med lange spader. Derpå fulgte yderligere ca. 100 uden spader. Alle var iført uniform. Til sidst i toget gik ca. 30 NSU'er fra partiets ungdomsafdeling National-Socialistisk Ungdom, ledet af maskinbygger Hans Friis, Øster Løgum, bror til Jes Friis. Tilsammen var der en 275 mand i optoget. Optoget afmarcherede omtrent kl. 15. Det fulgte ruten Aabenraavej- Sønderbro-Møllepladsen-Lavgade. ${ }^{31}$ Ved Sønderbro stødte sysselleder Jes Asmussen til optoget. Han gik ved siden af Jes Friis til Højskolehjemmet. Friis var klar over, at marchen var ulovlig, men regnede med, "at selve marchen ville gøre et sådant indtryk på politiet og befolkningen, at der ikke ville blive skredet ind imod dem". ${ }^{32}$

Samtidig med afgangen mødte SA-mand, lagerist Lorenz Peter Kjær fra Aabenraa, efter ordre fra partiet op på politistationen for at orientere politiet om, at 400 mand marcherede ad Aabenraavej ind mod byen. Han var klædt i grøn dobbeltradet jakke med skulderstropper, spidsbukser i det samme stof, lange støvler, brun skjorte prydet med to stjerner og et firtal, brunt slips, brunt lædertøj inklusiv skrårem og pistoltaske og en blå kasket forsynet med emblemer. Pistoltasken var tom, så Kjær overtrådte ikke våbenloven, men tydeligvis uniformsforbuddet, hvorfor han efter afhøring blev arresteret og indsat $i$ arresten. Haderslev politi viste dermed straks nultolerance overfor brud på uniformsloven. 
Det var i tråd med rigsadvokatens cirkulære af 30. november 1940, hvor han indskærpede en nøje overholdelse af uniformsforbuddet, som det senest var formuleret i loven af 30. marts 1940: "Enhver åbenbar eller formodet overtrædelse af loven bør derfor uopholdelig gøres til genstand for efterforskning og strafferetlig forfølgning". ${ }^{33}$

Ifølge Henning Poulsen var der en mening med, at Lorenz Peter Kjær skulle bruges som budbringer. Om morgenen den 9. april 1940 havde han efter de danske troppers tilbagetog mod Haderslev på egen hånd stillet sig op i sin SA-uniform i Tøndervejskrydset i den sydlige del af Aabenraa og vist de tyske køretøjer på vej videre nordpå. Situationen blev foreviget på et foto, som gik Danmark rundt. Det var til stor gene for DNSAP, der herved blev udstillet som et landsforræderparti. Ikke desto mindre blev Kjær i juni måned udpeget til gruppefører i SA. ${ }^{34}$

Da Kjær var bag lås og slå, gik Hartmann sammen med politiassistent C. J. Toft og 7-8 betjente, som forinden var alarmeret, fra stationen på Gammelting mod syd for at standse optoget. Lige uden for stationen observerede de en holdende personbil med nummerpladen D.1872. Den havde en hagekorsvimpel i bagruden og indeholdt en del civilt tøj. Føreren fortalte, at det tilhørte SA'erne. Hartmann gav ordre til at arrestere føreren og beslaglægge både bil og beklædning og køre bilen ind i arrestens aflåste gård. Den kontante linje blev fortsat fulgt.

\section{Den første konfrontation i Lavgade - forstærkninger tilkaldes}

Lidt før klokken 15.30 mødte Hartmann og hans betjente optoget ud for Lavgade nr. 1. Hartmann rakte armen i vejret og gav flere gange optoget påbud om at standse. Men forgæves. Jes Jensen Friis råbte: "Vi lader os ikke standse". Han gav optoget kommandoen "Fremad" og gjorde med hånden tegn til dem, der gik bag ham, om at følge trop. Nogle betjente trak på egen hånd staven, men deltagerne i optoget hævede deres spader med den skarpe kant vendt ud mod betjentene, klar til hug. Hartmann gav nok engang Friis besked på at standse, men denne svarede: "Vi vil se, hvem der er de stærkeste". De få betjente blev skubbet til side, og optoget brød igennem politikæden. Da SA'erne passerede Hartmann, truede de fleste ad ham med deres spader. Hartmann gav sine betjente ordre til at følge efter optoget til Højskolehjemmet.

Optogets marchrute gik herefter via Apotekergade, Bispegade, Storegade, Vestergade, Pladsgade og Storegade til Højskolehjemmet, der ud- gjorde Storegade 55. Højskolehjemmet havde indkørsel mellem nr. 53 og 57, men lå ellers tilbagetrukket på grunden ned mod Dammen, hvor nu Hotel Norden ligger. Efter ankomsten blev de store spader samlet sammen uden for mødesalen, hvor de blev sat under bevogtning, mens de små spader blev taget med ind i salen. ${ }^{35}$

Sideløbende hermed gik Hartmann tilbage til politistationen for at indkalde assistance. Her var den erfarne overbetjent A.N. Jensen kommet tilstede og havde overtaget vagten. Han fik nu ordre til at søge politimestrene i Aabenraa, Kolding og Odense om assistance.

I den forbindelse tilkom der politimester Aage Agersted i Aabenraa en særlig rolle. Byen var som nævnt hjemsted for den centrale sønderjyske udrykningsenhed, der hurtigt skulle afsted, og som næstkommanderende hos den sønderjyske politiadjudant, amtmand Kr. Refslund Thomsen, var Agersted en nøgleperson i tilkaldelsen af yderligere personel og i ledelsen af de samlede styrker. Herom hedder det i politimester Aage Agersteds beretning: "Uagtet vanskelighederne ved en søndag eftermiddag at få samlet styrken, der hovedsagelig består af honorarlønnede betjente, der ikke har telefon, lykkedes det i løbet af ca. 10-15 minutter at få udrykningsvognen afsted med delingsfører og ca. 17 mand (mere kan vognen ikke rumme). Styrken kom straks efter ankomsten til Haderslev i kamp og fik 4 sårede, som måtte under lægebehandling. Efterhånden som yderligere mandskab mødte op, sendtes de afsted i personbiler, således at assistancen fra Aabenraa udgjorde 30 mand samt 6 kriminalpolitifolk. Hertil kom yderligere ca. 10 mand fra Graasten og ca. 10 mand fra Tønder. Jeg turde ikke blotte Sønderborg politikreds for mandskab, da der var politisk møde med indenrigsministeren som taler. Efter at have konfereret med politikommissær Holten, København, om yderligere assistance fra den øvrige del af landet og efter at have truffet de fornødne sikkerhedsforanstaltninger i min egen politikreds, tog jeg til Haderslev, hvor jeg assisterede politimester Hartmann til kl. 3 morgen med ledelsen af de samlede politistyrker". ${ }^{36}$

På et ukendt tidspunkt "om eftermiddagen" kontaktede Hartmann tillige den tyske værnemagt ved den lokale kommandant, major Enemark. Hartmann anmodede om at få to tyske officerer opstillet ved Højskolehjemmet, så de kunne bortvise tyske soldater, der kunne tænkes at involvere sig i tumulterne. Hartmann skriver herom: "Dette skete, og affæren forløb uden gnidning med militæret eller nogen som helst indblanding fra dettes side" ${ }^{37}$ Både Hartmann og Enemark overholdt således den aftale, som var indgået efter Roskilde-demonstrationen. 
Den anden konfrontation

- ved indkørslen til Højskolehjemmet

Fra politistationen gik Hartmann til Højskolehjemmet, hvor han ankom ca. kl. 15.45. På det tidspunkt var næsten alle deltagere i det offentlige møde på plads inden for i Højskolehjemmet. Hartmann lod de endnu fåtallige politimænd bevogte hovedindgangen, ligesom han lod dem rydde gaden, så tilskuerne blev trængt 60-80 meter tilbage til hjørnet af Vestergade-Storegade og Pladsgade-Storegade, som politiet let kunne bevogte.

Kort efter, at den første forstærkning var ankommet kl. 16.30 - det var 30 betjente fra Aabenraa og 7 fra Kolding - stillede to spadebevæbnede SA'ere sig op som en vagtpost ved indgangen til Højskolehjemmets område. Det skete formentlig på ordre fra kolonnefører Laust Andersen, som Jes Friis havde givet kommandoen over vagten ved mødelokalet. ${ }^{38}$ Politiets styrke var nu oppe på ca. 50 mand, og Hartmann gav sine folk ordre at anholde de to vagter, "idet jeg bemærkede, at de dog alle sammen skulle anholdes og man kunde begynde med dem". Med slag og spark modsatte de to sig anholdelsen, som ikke desto mindre blev gennemført.

Da SA'erne nede ved Højskolehjemmet erfarede dette, lød der en fløjte uden for salen fulgt af ordren "SA ud", hvorefter næsten alle SA'er brød op fra det igangværende møde, løb ud af salen og greb deres spader. ${ }^{39}$ En større skare bevæbnet med spader stormede frem mod politiet for at befri de to vagter. Imens råbte de gentagende "For Danmarks ære, frihed og ret". ${ }^{40}$ Hartmann lod betjentene danne kæde hen over indkørslen og gav dem ordre til at trække stavene. SA'erne angreb med korte og lange spader, cyklepumper, gummistave og gærdestaver. Det kom nu til et alvorligt slagsmål, hvor tre politifolk fra Aabenraa blev såret i hænder og arme. De blev forbundet af Arbejdernes Samariter-Korps, som havde oprettet en forbindingspost i Storegade 52, og derfra bragt til amtssygehuset til fortsat behandling. Flere SA'ere blev slået ned med politiets stave. Politiet kom dog snart til kort over for SA'ernes større mængde og lange spader, og det trak sig tilbage til indkørslen til Højskolehjemmet, medbringende de to anholdte. Hartmann gav sine betjente besked på at holde denne position og gav dem tillige ordre til trække pistolerne og tage ladegreb, men også til, at der kun måtte skydes på politimesterens ordre. Flere betjente huskede det siden sådan, at overbetjent Jacobsen fra Aabenraa gav ordren til at trække pistolerne..$^{41}$ Det strider ikke nød- vendigvis mod Hartmanns udsagn om, at han gav ordren - han kan have givet den til Jacobsen, som så råbte den ud til betjentene. Brugen af pistolen var ifølge rigspolitichefens instruks begrænset til nødværgesituationer, men en sådan måtte også siges at foreligge.

Synet af pistolerne fik SA'erne til at indstille angrebet et par meter fra politiet. Fylkefører Jes Friis trådte nu frem foran sine SA'ere. Ifølge Hartmann havde han "helt mistet besindelsen og opfordrede politiet til at skyde på ham". En betjent huskede Friis råbe: "Skyd på mig, så dør jeg for sagen". Opfordringen blev dog ignoreret. En SA-mand fra Christiansfeld råbte ifølge samme betjent: "Fy, fy, I skulle skamme jer. Vi er også danskere". ${ }^{42}$ En anden betjent huskede, at Ejnar Jørgensen ved synet af pistolerne råbte: "Den skulle I have brugt den 9. april, men da var I for feje til det", hvortil betjenten indigneret svarede: "De skulle skamme Dem som dansk mand at komme med en sådan udtalelse. Fy, hvor må De skamme Dem". 43 "Måtte-Madsen" fra Aabenraa opildnede sine kammerater: "Slå dem ned de mordere". ${ }^{44}$ Udtalelserne gengives naturligt nok med variationer fra betjent til betjent, men fast står det, at blodet var kommet i kog, i hvert fald hos nazisterne, men sikkert også hos betjentene.

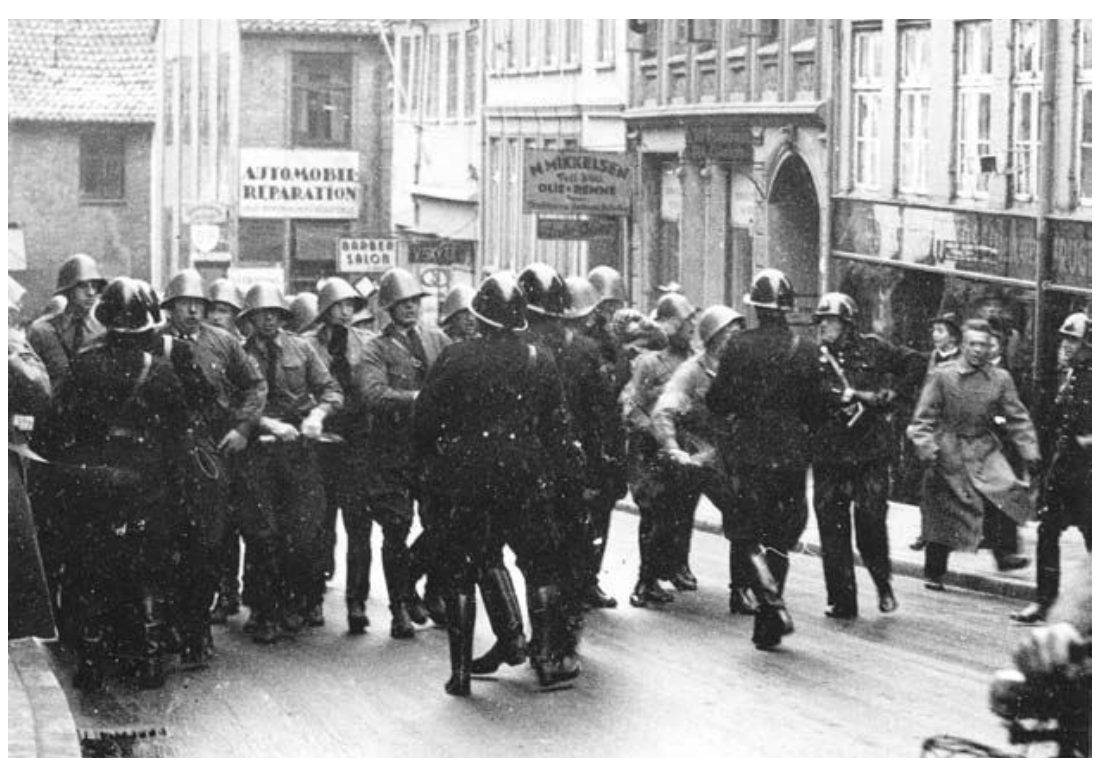

I Lavgade trodser SA politimester Hartmanns påbud om at standse marchen og bryder den svagt bemandede politikæde. Foto: Rigsarkivet Aabenraa, Haderslev politi nr. 909. 
Under en forhandling med overbetjent Jacobsen forlangte Friis de to anholdte sat fri. Det gik Hartmann selvfølgelig ikke med til. Hartmann opfordrede Friis og hans folk til at gå tilbage til Højskolehjemmet og fortalte dem, "at de indlod sig på noget, hvis følger de ikke var i stand til at overse". SA'erne blev imidlertid stående. I mellemtiden lykkedes det de to anholdte at stikke af fra den udrykningsvogn, som de var anbragt $\mathrm{i}$ bag ved politikæden, og slippe ind til kammeraterne på Højskolehjemmet. Med en skovl havde de haft held til at forhindre betjentene $i$ at lukke døren til udrykningsvognen ordentligt, og det var ikke muligt for den ene betjent, som blev ved vognen, mens de andre styrtede deres trængte kolleger til hjælp, at modstå presset fra de to anholdte. ${ }^{45}$ Flugten var ikke så lidt af en brøler fra politiets side. Den viser, hvor trængt betjentene var, men den løste op for den spændte situation ved indkørslen, for nu kunne Hartmann overtale SA'erne til at gå tilbage til Højskolehjemmet. Det skete med bemærkningen om, at de alle som en ville blive anholdt efter dette. SA'erne gik ind i Højskolehjemmet, hvor mødet fortsatte. Hartmann lod nu alle udgange fra Højskolehjemmet

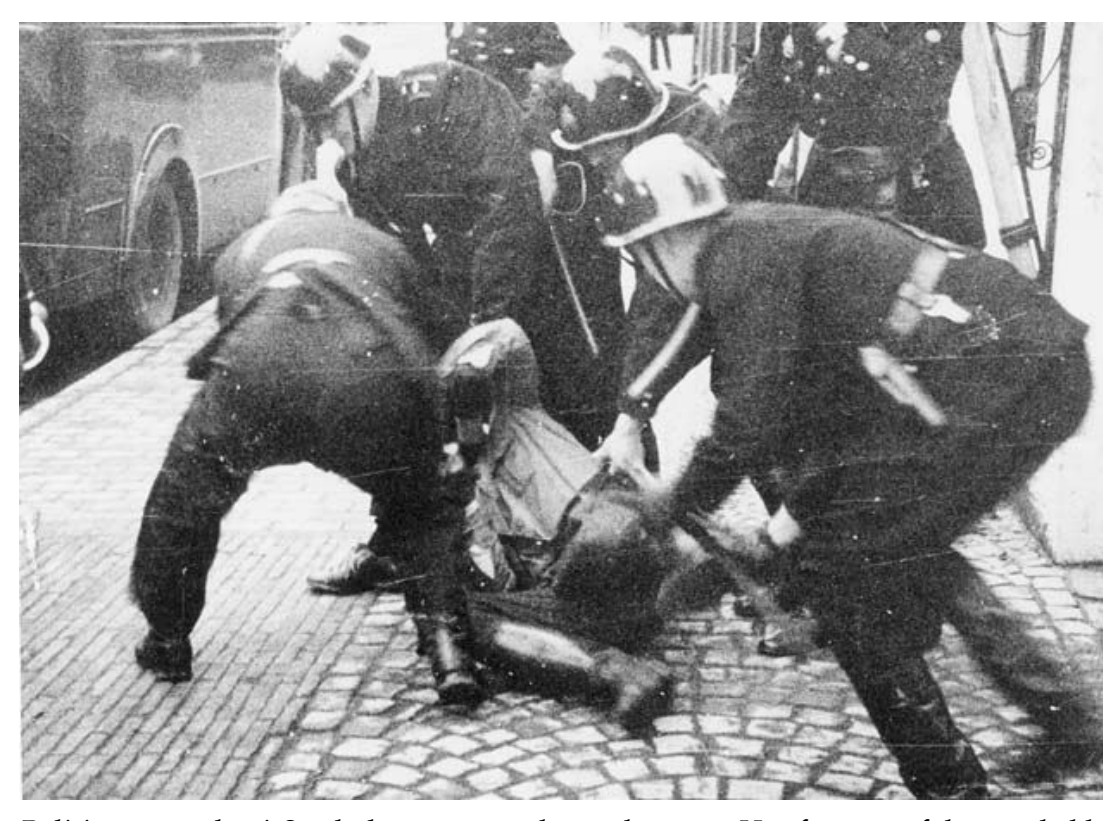

Politiets optræden i Spadeslaget var resolut og kontant. Her føres en af de to anholdte spadevagter foran Højskolehjemmet ud til en udrykningsvogn. Foto: Rigsarkivet Aabenraa, Haderslev politi nr. 909. blokere, så ingen SA'ere kunne slippe ud. Der blev sendt bud efter tåregasbomber. Hartmann tilkaldte tillige en motorsprøjte fra Falck, som med kolde vandstråler kunne pacificere SA'erne med deres lange spader. Dette "våben" nævntes ikke i rigspolitichefens instruks, men de fleste vil nok være enige om, at det sammenlignet med tåregas og især med skydevåben var mere skånsomt mod SA'erne.

$\mathrm{Og}$ så ventede politiet ellers på flere forstærkninger. Kl. $18 \mathrm{kom}$ fem mand fra Toftlund, kl. 18.15 to overbetjente og 13 mand fra Tønder, kl. 18.30 en overbetjent og 14 mand fra Graasten samt en politiassistent, to overbetjente og 24 mand fra Odense. Kl. 20 stødte yderligere 24 mand til fra den fynske hovedstad. Styrken nåede dermed op på 130 ordensbetjente. ${ }^{46}$

\section{Det offentlige møde}

Resten af DNSAP's offentlige møde blev afviklet i ro og orden. Det skal her skildres fra begyndelsen. Kaptajn Lærum ankom i en sort uniform lidt i kl. 16, sysselleder Jørgensen først ved 16.20-tiden i bil sammen med fabrikant C.C. Fischer fra Aabenraa. Efter Jørgensens ankomst blev DNSAP's faner og Dannebrog ført ind i salen, og mødet begyndte. Fylkefører Jes Friis gav alle SA'ere besked på at blive i salen efter mødet, så de kunne marchere til deres cykler i samlet flok. Sysselleder Jes Asmussen bød velkommen og gav straks ordet til kaptajn Lærum. Vi kender til Lærums tale fra det bevarede manuskript samt fra overbetjent Riis' referat. De to kilder er mildt sagt ikke overensstemmende.

Ifølge overbetjent Riis indledte Lærum med et hårdt angreb på regeringen Stauning for at have svigtet både op til den 9. april og på selve dagen. Han udtalte, "at lige som Tyskland havde sine novemberforbrydere havde Danmark sine 9. april forbrydere" og han kaldte Stauning for en "pjalt" og hele regeringen for "mordere" og "engelskvenlige pjalter". Under Lærums tale var det, at SA'erne kl. ca. 16.30 blev kaldt ud, og talen blev derfor afbrudt, så længe kampen udenfor stod på. Da denne var forbi, kom ca. 120 SA'ere igen ind i salen, denne gang med deres spader på skuldrene. I to rækker marcherede de ind i salen, og oppe ved talerstolen svingede den ene række til venstre, den anden til højre, således at SA'erne dannede en ring uden om tilhørerne med fronten imod midten af salen. Sådan blev de stående under resten af mødet. Derefter genoptog Lærum ifølge Riis sin tale med ordene: "Her kom vore brune drenge, der skal danne kærnen i Danmarks fremtidige 


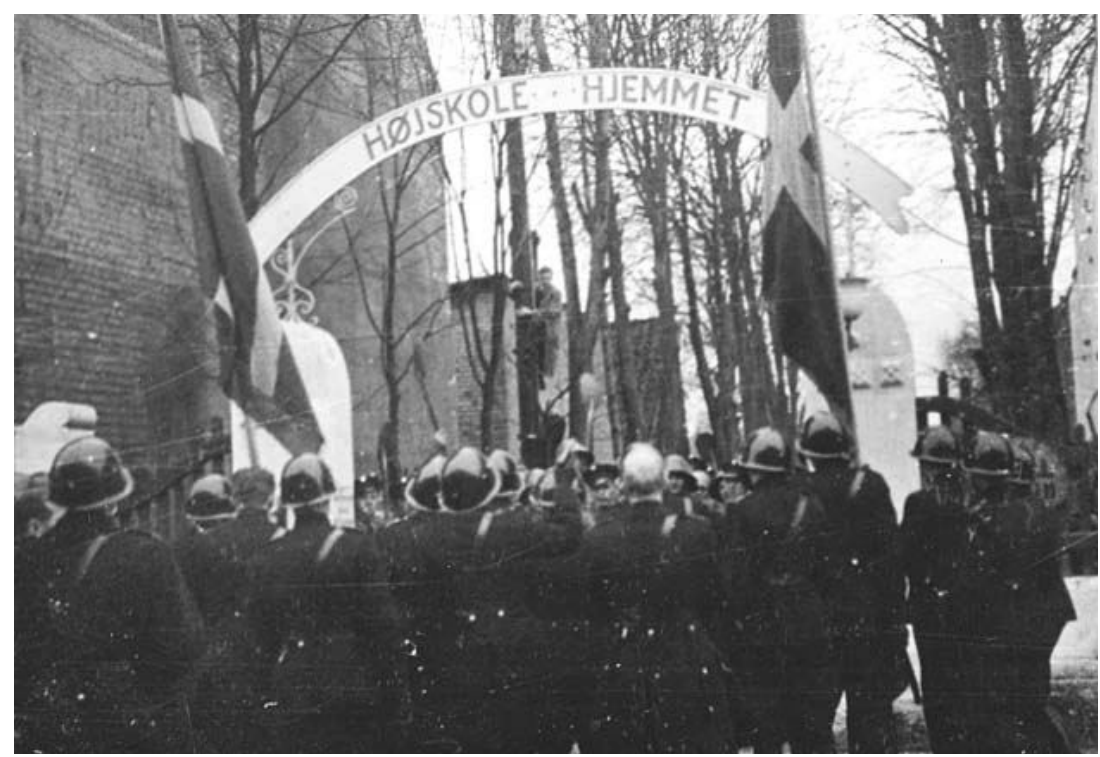

For at befri de to anholdte spadevagter angriber SA politiet $i$ indkørslen til Højskolehjemmet. Bemærk en af de lange spader løftet til slag. Foto: Rigsarkivet Aabenraa Haderslev politi $n$ r. 909.

hær, og med vor ånd og vore spader og det der er endnu skarpere skal vi jage hele banden på Christiansborg pokker i vold, ligesom vi for lidt siden fejede politiet bort". Denne udtalelse blev mødt med bravoråb og trampen i gulvet af SA'erne. Om DNSAP's magtovertagelse skulle Lærum stadig ifølge Riis have sagt, at "hvis det danske folk ikke vil forstå os, da må det selv tage følgerne for hvad der sker - for til magten vil vi, og vi kommer det".

Efter Lærum fik Jørgensen ordet. Efter at have nævnt sit arbejde blandt kammeraterne på Sjælland fortsatte han ifølge Riis: "Han sagde endvidere, at disse kammerater kun venter på signalet til at marchere, muligvis det skal komme fra Sønderjylland, muligvis begynder opgøret eller oprøret endnu i dag ved den her lejlighed, de er parate og venter kun på signalet". Så vidt overbetjent Riis. ${ }^{47}$

Foreholdt disse citater fra Riis bestred kaptajn Lærum ganske at have udtalt sig således. Ligeledes bestred han vidneudsagn fra to SA'ere, som under deres afhøring havde citeret Lærum for at sige "at Danmarks nuværende regering, der havde optrådt som forbrydere den 9 . april, ville blive fjernede, som forbryderne blev det i Tyskland i 1933".
Til støtte for sin benægtelse fremlagde Lærum en uge efter Spadeslaget sit manuskript, som han hævdede i alt væsentligt at have holdt sig til. Manuskriptet indeholder ganske rigtigt ikke sådanne udtalelser. Lærum vedgik ifølge dette, at det var målet for DNSAP at få regeringen Stauning væk, men "vi bekæmper regeringen med legale midler". Om den 9. april udtalte Lærum, at den var et "forsmædeligt resultat" af den førte politik, der gjorde folk til "svæklinge". Om tiden efter: "På systemets gamle dage, dvs. siden den 9. april har man vist stor fejhed såvel indadtil som udadtil. Man søger at dække sin fejhed indadtil ved at kue folket med latterlige tvangsforanstaltninger". Resten af talen var - stadig ifølge manuskriptet - en afdæmpet gennemgang af DNSAP's ideologi og politik. Overbetjent Riis fik manuskriptet til gennemlæsning, men han fastholdt, at Lærum havde udtalt sig som citeret i hans rapport. Senere, i marts, lykkedes det politiet at få et uvildigt vidne frem. Det var trafikassistent Peter Gunnar Thybjerg Nielsen fra Gørding, som havde deltaget i mødet som referent for Vestkysten. Også han huskede, at Lærums tale indeholdt langt skarpere vendinger end manuskriptet. ${ }^{48}$

Påstand stod mod påstand - men det forekommer i det mindste sandsynligt, at Lærum har sammenlignet "novemberforbryderne" i Tyskland, dvs. socialdemokraterne, som indgik våbenstilstanden med de vestallierede i november 1918, med den danske regering og dens kapitulation den 9. april 1940.

\section{Den tredje konfrontation}

- masseanholdelsen ved Højskolehjemmet

Det offentlige møde var forbi lidt efter k1. 18. De ikke-uniformerede deltagere forlod derefter Højskolehjemmet. Det drejede sig om ca. 120 mænd og kvinder. De stod ikke til anholdelse, og politiet lod dem passere afspærringen. Da Hartmann blev gjort bekendt med Ejnar Jørgensens ovenfor citerede ytringer om et muligt kup, fik han afbrudt telefonforbindelsen fra Højskolehjemmet.

Ved 19-tiden indfandt kaptajn Lærum sig i uniform ved politiafspærringen ved indkørslen til Højskolehjemmet. Her præsenterede han sig som "rigsungdomsfører" og anmodede om frit lejde for NSU'erne. Hartmann gav ham derpå besked på at føre alle deltagere under 16 år ud af Højskolehjemmet i samlet flok og få Jes Friis til at komme ud til forhandling. Friis blev inde i salen, mens Lærum afgik med de yngste deltagere. De blev af politiet gelejdet ad Storegade mod syd gennem en 
meget stor mængde tilskuere, som politiassistent Toft betegnede som "mange tusindtallig". Bortset fra de mange fy-råb led ungdomsafdelingen ingen overlast.

Tiden gik. Omkring kl. 20.30 sendte Hartmann kriminalassistent Jacobsen, overbetjent Jacobsen samt kriminalbetjentene Nielsen fra Aabenraa og Balling fra Haderslev ind i Højskolehjemmet for at få Friis til at komme ud til forhandling. Denne gang indfandt han sig sammen med Jes Asmussen hos Hartmann, som nu gav Friis besked på, at SA'erne kun kunne slippe ud fra Højskolehjemmet, såfremt alle befalingsmænd fra optoget frivilligt lod sig anholde og transportere til politistationen, og såfremt resten i hold á 10 mand afgav deres spader, våben og uniformer til politiet og oplyste dette deres navne og adresser. Det gik Friis ikke ind på, og Hartmann gav nu via Friis SA-lederne en frist på 10 minutter til at overgive sig, hvorefter politiet ville trænge ind i Højskolehjemmet og anholde alle.

Jes Friis fik herefter lejlighed til at sætte sig i kontakt med Frits Clausen, der allerede var undervejs i bil til Haderslev. Friis gik atter ud til Hartmann og anmodede ham om udsætning, indtil partiføreren nåede frem. Det afviste politimesteren. ${ }^{49}$

Da anholdelserne åbenbart kun lod sig gennemføre under magtanvendelse, blev to delinger med Odensebetjente posteret på hver sin side af Højskolehjemmets sal, mens en 15 mand blev stillet op i haven øst for Højskolehjemmet og en halv snes ved brandvejen vest for dette. To delinger blev opstillet ved indkørslen, og resten blev sat til at afspærre gaden, gå patrulje og bevogte politistationen.

Inde i salen stod de spadebevæbnede SA'ere klar ved vinduer og døre. Efter udløbet af de 10 minutters ultimatum gav Hartmann besked på at slå en rude ind på hver side af salen og kaste en tåregasbombe ind gennem åbningen. Det fik SA'erne til at styrte ud af salen og gå til angreb på politiet for at bryde igennem. En betjent huskede siden, at nazisternes hornorkester imens spillede "Vi vestjyder trives bedst i blæst"..$^{50}$ Gennembruddet lykkedes ikke, og flere blev anholdt og anbragt i politiets udrykningsvogne under bevogtning. Denne gang slap ingen anholdte fri. I forbindelse med anholdelserne fik en politiassistent et åbent sår i panden efter at være blevet ramt af en spade, en betjent blev såret i højre underarm og en overbetjent ligeledes såret $\mathrm{i}$ armen. Under kampen forsøgte flere SA-folk at blænde politiet med stavlygter, men Hartmann svarede igen med projektørerne på udrykningsvognene.
For at spare sine betjente fik Hartmann rullet tre brandslanger ud og sat tryk på, og strålerne fik de tilbageværende SA'ere til at retirere til salen. De trivedes åbenbart ikke i hårdt regnvejr! Hartmann lod på ny tåregasbomber kaste ind. Det tvang SA'erne ud til vandstrålerne. Nogle forsøgte at undvige til siderne, hvor de blev afvist af politiet og sendt tilbage. Politiet benyttede også tåregas uden for Højskolehjemmet. Der var ikke andet at gøre for SA'erne end at kaste deres spader, række hænderne i vejret og overgive sig. Politiet fik dem ind på to rækker. En betjent huskede senere, at nogle af de anholdte på et tidspunkt rakte armen i vejret og råbte hurra, fordi Frits Clausen kom tilstede. ${ }^{51}$ Fra de to rækker blev de anholdte SA-ere i udrykningsvognene kørt til politistationen eller arresten i Haderslev, hvorfra 11 mand senere blev kørt til arresten i Aabenraa og 24 til Toftlund. I alt blev der anholdt 239. Heraf var en snes kvinder, civile eller unge under 16, som så snart som muligt blev sat på fri fod. K1. 23.30 var aktionen forbi.

Under det offentlige møde og under aftenens anholdelsesaktion samlede en tusindtallig skare sig uden for Højskolehjemmet, hvor den sang danske nationalsange og råbte fy efter de arresterede SA-folk.

\section{Efter slaget}

Politiet havde sat sin magt igennem og hævdet sin autoritet. Ifølge Agersted havde betjentene bestået prøven. Det var hans opfattelse, "at hele det udkommanderede personale, herunder de honorarlønnede betjente, arbejdede godt, og at der ikke blev anvendt hårdere midler end nødvendigt for at gennemføre politiets opgave... Det må dog bemærkes, at jeg med hensyn til den sønderjyske udrykningsdeling savnede gruppeførere (overbetjente eller ældre, faste politibetjente), idet delingsføreren, overbetjent Jacobsen, der udførte et fortrinligt arbejde, var eneste befalingsmand ved delingen". 52

Under kampene fik 23 betjente større eller mindre skader ved sammenstødene og måtte under behandling. De værste skader var en brækket arm, et dybt kødsår ind til knoglen i panden, et brud på en overarmsmuskel og en brækket lillefinger, mens resten mestendels var hævelser, blodudtrædninger og ømhed. Én måtte indlægges på amtssygehuset, en anden måtte holde sengen nogle dage. Skaderne skyldtes i de fleste tilfælde hug fra spade. De skadede betjente fordelte sig med 9 fra Odense, 6 fra Haderslev, 4 fra Aabenraa, 3 fra Kolding og 1 fra Tønder. ${ }^{53}$ 


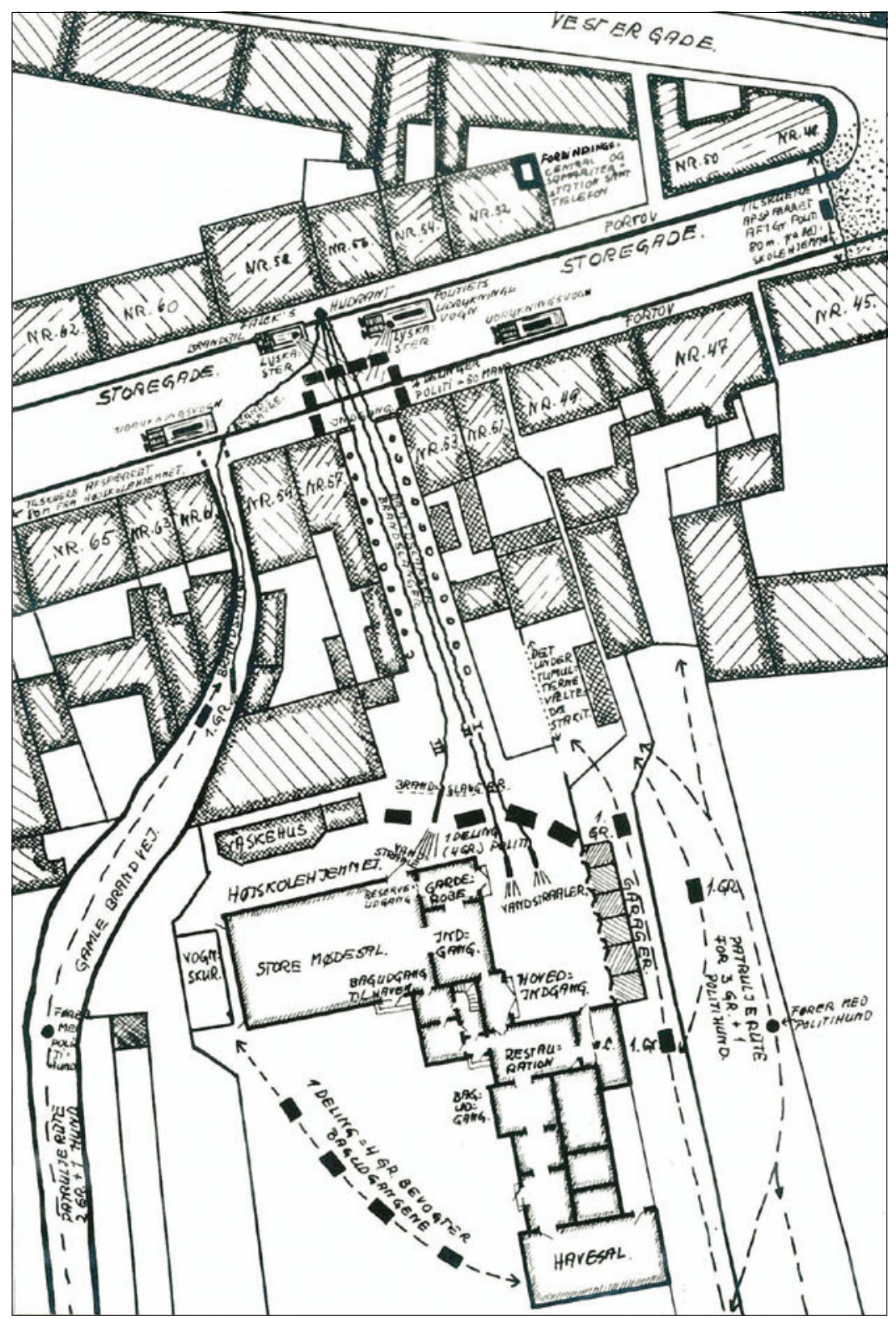

Politiets kort over Højskolehjemmet med angivelse af de forskellige delingers opstilling, de udrullede brandslanger, publikums placering m.m. Foto: Rigsarkivet Aabenraa, Haderslev politi nr. 909.
Også blandt SA'erne var der sårede, og kredslægen blev kaldt til arresten for at yde dem hjælp. En havde fået et slag over venstre underarm, som var hævet op, en anden havde fået en overfladisk flænge i hovedbunden, et par havde fået et blåt øje, en nogle alvorligere hudafskrabninger og 5-6 nogle overfladiske skrammer. Kredslægen sluttede sin rapport således: "Som et almindeligt indtryk skal jeg udtale, at kun ganske få havde fået alvorlige knubs, men ingen af arrestanterne havde fået alvorlige læsioner, der kunne tænkes at forårsage varige mén." 54

Forholdet mellem antal sårede hos politiet og SA og læsionernes forskellige alvor modsagde de anklager om "polititerror i Haderslev", "angrebets infame brutalitet" og politiets "torturmanér", som den nazistiske avis Fædrelandet fremsatte. Avisen kritiserede, at politimester Hartmann ikke havde afventet Frits Clausens ankomst, så en mindelig ordning kunne være opnået ved hans mellemkomst. Den gik hårdt i rette med anvendelsen af tåregas, der også ramte "de derinde værende kvinder og børn", hvoriblandt skulle have været Dotte Friis, lederen af DNSAP's kvindegrupper i Sønderjylland, samt en datter og en otteårig søn af sysselleder Jes Asmussen. Fædrelandet gjorde også en del ud af, at tåregasbomberne kunne have antændt salen, så alle var brændt inde. Den skildrede tillige, hvorledes en ung mand, der snublede og var længe om at rejse sig, var blevet "tampet med kniplerne" af en håndfuld betjente, så han måtte bæres bevidstløs bort. Det var tydeligvis avisen om at gøre, at den ikke slog alle politifolk over en kam, men alligevel skrev den: "Men det, der præsteredes af en del af politiets mandskab i søndags i Haderslev er af en så oprørende karakter, at vor bevægelse en skønne dag kommer til at tage stilling til et meget alvorligt problem med hensyn til politiet." Hartmann blev sat i klasse med mænd som Hans Hedtoft, Hartvig Frisch og "den ondskabsfulde dværg" Christmas Møller. ${ }^{55}$

Ansvaret for, at der stadig befandt sig kvinder og børn i Højskolehjemmets sal, efter at der var givet både civile og børn og unge mulighed for frit at forlade stedet, må hvile tungt på de nazistiske ledere - herunder ikke mindst på Jes Asmussen som far til to børn og Jes Friis som bror til Dotte Friis. Sandsynligvis afspejler dette, at Asmussen og Friis ikke havde regnet med, at politiet ville tage tåregas - og måske heller ikke brandsprøjter - i brug, men at det ville angribe SA'erne med kniplerne. Den manglende vilje til at gå ind på Hartmanns ultimatum tyder i samme retning.

Politifolkene styrkede sig med mad og drikke på Harmonien, og derefter blev de udenbys sendt hjem, først folkene fra Odense, derefter fra 
Kolding, Gråsten, Toftlund og Tønder, mens 15 mand fra Aabenraa blev tilbage for at gå på patrulje i byen og for at hjælpe til med afhøring af de mange anholdte. Afhøringerne begyndte straks efter aktionen og var først ført til ende næste dags aften ved 18-tiden. Da var en snes mand blevet fængslet, mens resten var blevet løsladt og nogle få indsat til afsoning af bøder.

I forbindelse med Spadeslaget beslaglagde politiet af bevæbning 106 lange spader og 20 korte, en tynd jernstang på en meters længde, en træstok af samme længde, en spadserestok, 10 almindelige cykelpumper, der også var brugbare som slagvåben, samt 20 gråmalede stålhjelme og 15 hjelmbæreremme. Dertil kom en række uniformsgenstande såsom 13 sorte kasketter med blanke skygger, 2 brune livremme med skråremme, 1 brun skjorte, 1 hagekorsarmbind samt 29 tornystre med og uden indhold og endvidere nogle Dannebrogs- og hagekorsvimpler og faner, nogle musikinstrumenter, civilt tøj og forskelligt andet. ${ }^{56}$

Forulempelse af løsladte SA-folk

- amnesti - hæder til betjentene

De anholdte kunne fængsles indtil den 27. december, men ingen SAmænd kom til at holde jul bag tremmer. De fængslede blev løsladt, efterhånden som de var afhørt af betjente fra Haderslev eller andre sønderjyske stationer. For de fleste skete det mandag den 9. december. Det tyske mindretals avis Nordschleswigsche Zeitung bragte den 10. december en længere omtale af, hvorledes adskillige løsladte var blevet forulempet af menneskemængden, når de forlod arresten i Laurids Skausgade og gik over Gammelting og ned ad Nørregade til rutebilstationen. Avisen skrev, at "de uden beskyttelse blev overladt til vilde horder, der ofte i umiddelbar nærhed af politibetjentene slog dem til jorden, uden at der blev skredet ind. Denne skandale varede i flere timer. Først hen mod aften blev de løsladte SA-mænd fulgt til banegården under politiets beskyttelse". Om politiet skrev avisen, at ordensmagten ved denne lejlighed havde løst sin opgave dårligt eller slet ikke. ${ }^{57}$

Kritikken af Haderslev politi førte til, at politimester Hartmann gav overbetjent A.N. Jensen besked på at optage en særskilt rapport om forholdene ved løsladelserne. Heraf fremgik, at alt disponibelt mandskab var på gaden for at holde opsyn med de usædvanligt mange mennesker til langt efter mørkets frembrud. Afhøringer af de patruljerende betjente viste, at de konstant måtte give folk besked på at passere gaden

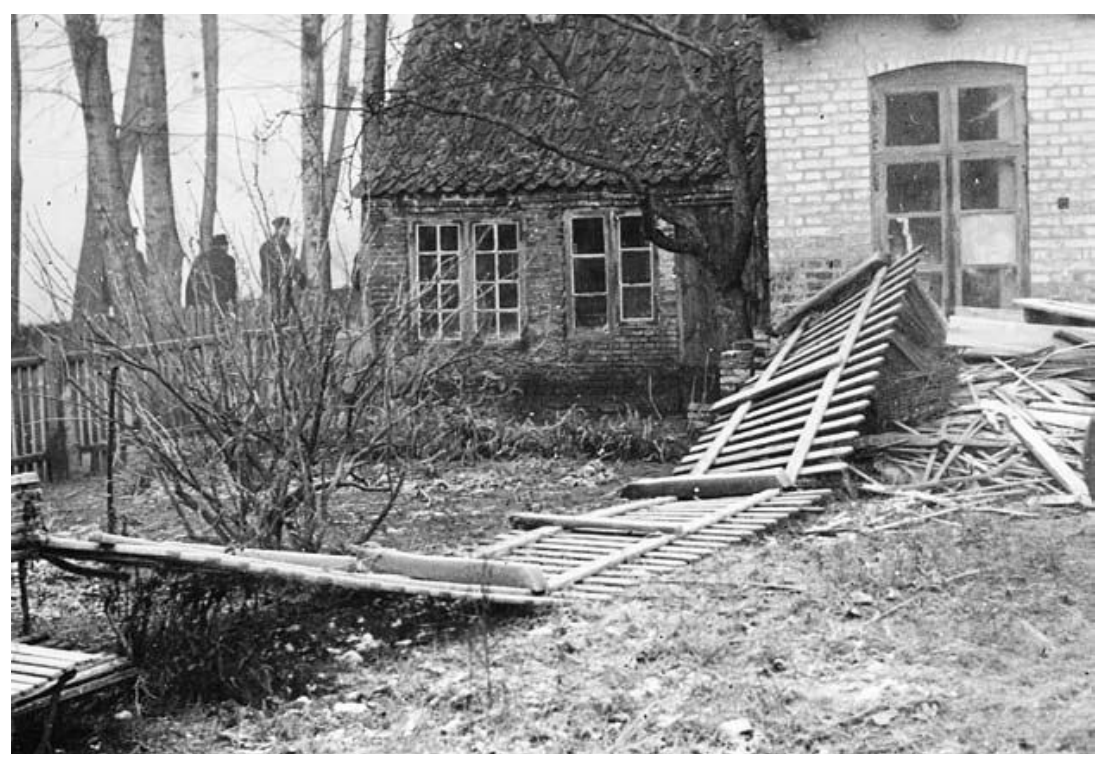

For at undvige politiets tåregas og brandsprøjter væltede SA'erne et stakit mellem Højskolehjemmet og ejendommen mod øst. Foto: Rigsarkivet Aabenraa, Haderslev politi nr. 909.

for at forhindre sammenstimlen i klynger. Det var mest børn, bybude, lærlinge og andre unge mennesker, som var på gaden. Betjentene bemærkede, at der blev råbt "fy!", "føj!" og "landsforrædere" og truet ad de løsladte, som "blev fulgt på vej" af skarer af nysgerrige. Betjentene kunne over for A.N. Jensen oplyse fire tilfælde af korporlig forulempelse. En løsladt nazist fik, skønt han blev ledsaget af en betjent på få skridts afstand, et knytnæveslag i hovedet på Jomfrustien, så han tumlede om. Betjenten kunne ikke nå at pågribe den skyldige, der straks forsvandt ind i mængden, uden at efterlade den ramte ubeskyttet. En anden blev slået ned i Nørregade og fik småskrammer i ansigtet. En tredje fik et slag i ansigtet, så læben blødte, formentlig på Teaterstien på vej til banegården. En fjerde fik et drag over nakken i Gåskærgade..$^{58}$ En række senere afhøringer af civile vidner førte til nogenlunde det samme resultat. ${ }^{59}$

Nordschleswigsche Zeitungs skildring var således ikke grebet ud af luften. En håndfuld SA-folk havde fået bank, og politiet havde besvær med at opretholde lov og orden, om end det næppe var så passivt som hævdet i avisen. Det var således ikke kun på Højskolehjemmet om sønda- 
gen, at gemytterne var i kog - det var de også ude i byen om mandagen. Haderslev fulgte dermed mønstret fra hovedstaden, hvor københavnere havde givet nazister bank på vejen hjem fra "Den lille hornblæser".

Løsladelserne fortsatte i de følgende dage uden dramatik. Fylkefører Jes Friis blev som den sidste sat på fri fod den 22. december, så ingen sønderjyske SA-folk kom til at holde jul i arresten. Ejnar Jørgensen blev samme dag overgivet til Roskilde arrest til afsoning af en tidligere straf.

Det var planen, at de løsladte senere skulle for retten for at få udmålt deres straf. Men sådan kom det ikke til at gå. Den 11. december 1940 skrev Frits Clausen til understatssekretær Luther i det tyske udenrigsministerium for at få besættelsesmagten til at fjerne den danske regering. Her vedlagde han et udklip med Nordschleswigsche Zeitungs artikel som dokumentation for hans påstand om, hvorledes de danske nationalsocialister blev brutalt forfulgt. ${ }^{60}$

Den 18. december blev DNSAP's situation diskuteret på et møde i det tyske udenrigsministerium mellem Luther, Renthe-Fink og Ribbentrop. Ribbentrop gav her Renthe-Fink ordre til at standse den påståede hetz mod de danske nazister. ${ }^{61}$

Ved nytårstid rejste Renthe-Fink spørgsmålet over for udenrigsminister Erik Scavenius og foreslog en amnesti til alle deltagere i Spadeslaget begrundet med ønsket om politisk afspænding. Den 21. januar 1941 foreslog han også amnesti overfor Stauning. Der blev herefter indledet forhandlinger. ${ }^{62}$ På dansk side var man ikke uvillig til en bred amnesti til SA-folkene, men den måtte ikke omfatte personer, som bevisligt havde gjort sig skyldige i vold eller trusler om vold mod politifolk, da dette ville underløbe politiets autoritet. I en forhandling mellem udenrigsministeriets direktør Nils Svenningsen og Paul Kanstein fra gesandtskabet anerkendte sidstnævnte dette synspunkt og tog tillige til efterretning, at ca. 30 ville blive retsforfulgt, mens ca. 190 ville gå fri. Kanstein blev imidlertid underkendt af gesandten og erstattet i forhandlingerne med dr. Stahlmann. Gesandtens holdning var, at alle skulle gå fri, ellers ville en afspænding ikke blive opnået. Svenningsen og de øvrige danske forhandlingsdeltagere spurgte så, om man fra tysk side ville øve indflydelse på DNSAP for at forhindre gentagelsestilfælde. Hertil svarede Stahlmann ifølge referatet, "at der jo ikke mellem tyskerne og de danske nationalsocialister bestod en sådan forbindelse, at der fra tysk side kunde gøres noget i den antydede retning. En påvirkning af de danske nationalsocialister ville jo være en indblanding i interne danske forhold, og noget sådant lå jo tyskerne ganske fjernt".
Da man fra dansk side tørt bemærkede, "at selve denne forhandling vel også måtte siges at være indblanding i interne danske forhold", benægtede Stahlmann, at dette var hensigten.

Svenningsen foreslog derpå afstraffelse af Jes Friis og en tre-fire andre ledere. Stahlmann mente, man i så fald kunne nøjes med Friis. Rigspolitichefen svarede, at man så risikerede at gøre ham til martyr. Fra dansk side fremlagde man et brev af 11. februar 1941 fra Jes Friis til politimester Bjerre i Graasten, hvori Friis advarede Bjerre mod at retsforfølge SA-folk og truende skrev: "De er sikkert også klar over, at en nyordning i vort land sker inden for en overskuelig tid, hvorefter enhver der driver politiske forfølgelser vil blive krævet til ansvar". Herefter kunne Stahlmann godt se, at en eftergivelse af Friis' straf kunne virke særlig uheldig, og han ville forelægge det danske synspunkt for gesandten. Renthe-Fink ville imidlertid ikke gå med til en strafforfølgelse mod Jes Friis eller andre ledere, men kun mod personer, som påviseligt havde udøvet vold. Han mente i øvrigt, at statsministeren havde givet tilsagn om fuld amnesti ("en ordning uden indskrænkninger") allerede ved de første samtaler. Rigspolitichefen fandt det nærmest umuligt at udsondre den personkreds, som bevisligt havde slået politiet med spader. Det hele endte med, at udenrigsminister Scavenius gik ind på at give amnesti til alle under forudsætning af, at dette ikke fremover ville forhindre politiet $i$ at håndhæve uniformsforbuddet og straffe overtrædelser heraf. Rigsadvokaten fik derpå den 6. marts 1941 ordre til at frafalde tiltale mod alle fra Spadeslaget inklusive kaptajn Lærum. Pressen fik besked på ikke at omtale tiltalefrafaldet.

Efter Befrielsen overvejede Statsadvokaten i Sønderborg en genoptagelse af sagerne. ${ }^{63}$ Det endte med, at tre af deltagerne i Spadeslaget blev dømt for deres handlinger. ${ }^{64}$ For Jes Friis trak Spadeslaget endnu længere skygger. Da han i 1978 stillede op for Fremskridtspartiet ved amtsrådsvalget i Sønderjylland, blev han indhentet af sin fortid og måtte trække sin kandidatur tilbage. ${ }^{65}$

Kunne man ikke straffe SA-folkene under krigen, kunne man i hvert fald hædre betjentene og deres indsats. Politimester Hartmann indstillede den 21. marts 1941, at 22 af de 23 sårede betjente hver fik et honorar på $100 \mathrm{kr}$. uanset omfanget af deres skader, "idet alene beskadigelsen viser, at de pågældende politifunktionærer har været fremme i de forreste rækker". Overbetjent Hejstgaard fra Tønder, der var hårdt såret med en brækket arm over håndleddet efter et spadehug og måtte gennemgå en smertefuld sygebehandling, ønskede han at honorere med 
$400 \mathrm{kr}$. Endvidere indstillede politimesteren, at politiassistent C.J. Toft fra Haderslev, konstitueret politiassistent Jens Jacobsen fra Aabenraa, politiassistent Godtfred Rasmussen fra Odense, overbetjent Andreas Nielsen Jensen fra Haderslev, overbetjent Laurentinus Hansen fra Kolding, kriminalassistent Arthur Odin Thor Bentzen fra Haderslev og overbetjent Ejner Hartvig Gjerste fra Odense blev udmærket med Dannebrogsmændenes hæderstegn. Indstillingen blev bakket op af justitsminister Harald Petersen, der ad den vej ville styrke moralen inden for politiet. Den 7. april fulgte Christian 10. indstillingen om hæderstegnene og tilkendegav dermed over for offentligheden, at kongemagt og regering bifaldt politiets optræden under Spadeslaget. ${ }^{66}$ For Harald Petersen blev belønningen af betjentene et søm i hans politiske ligkiste. Ifølge Henning Poulsen var den udslagsgivende for, at han efter tysk pres måtte træde ud af regeringen i juli $1941 .^{67}$

\section{Konklusion}

Spadeslaget den 8. november 1940 i Haderslev udsprang af en demonstrationsmarch med spader arrangeret af det sønderjyske SA i tilknytning til et lovligt politisk møde på Højskolehjemmet, arrangeret af DNSAP i Barved og Ellum sysler. Den umiddelbart ansvarlige for marchen var fylkefører Jes Friis, Øster Løgum, men det må anses for sandsynligt, at partifører Frits Clausen i det mindste har været informeret om marchen og mødet og godkendt disse. Formålet med marchen var at bryde såvel uniformsforbuddet som forbuddet mod optog og demonstrationer og dermed skaffe DNSAP større handlerum i offentligheden.

Politiet skulle skride ind mod den dobbelte lovovertrædelse - og gjorde det. Det var for fåtalligt til at kunne standse marchen, der fortsatte hen til Højskolehjemmet. I mellemtiden tilkaldte politimester Hartmann forstærkninger, som indtraf under og efter det offentlige møde. Skønt mange kom så langt borte fra som Odense, bestod politiberedskabet sin prøve.

Da SA under mødet opstillede to spadevagter ved indgangen til Højskolehjemmets område, blev de arresteret af politiet. Det fik SA'erne til at styrte ud fra mødet, gribe deres spader og angribe politiet for at befri de to fangne kammerater. Det kom herunder til så alvorligt et slagsmål, at politimesteren måtte beordre sine folk til at trække pistolerne og klargøre dem til skydning, men kun skyde efter udtrykkelig ordre. I henseende til, at mange politifolk blev såret af SA'ernes lange spader, forelå der en nødværgesituation, og det var en rimelig disposition at true med skydevåben. Truslen skaffede den fornødne våbenstilstand til at føre forhandlinger, der dog endte i en hårdknude. Den blev først "løst", da de to anholdte flygtede, hvilket politiet nok kunne have forhindret.

Politimesteren afventede herefter samtlige forstærkningers ankomst og rekvirerede to andre magtmidler, nemlig tåregas og brandsprøiter. Ved brugen af dem lykkedes det at anholde samtlige SA-mænd, som befandt sig på Højskolehjemmet. Brugen af tåregas kom bag på SA'erne. Den var ikke taget i brug ved de tidligere DNSAP-uroligheder - og det er spørgsmålet, om ikke Spadeslaget var første gang, dansk politi

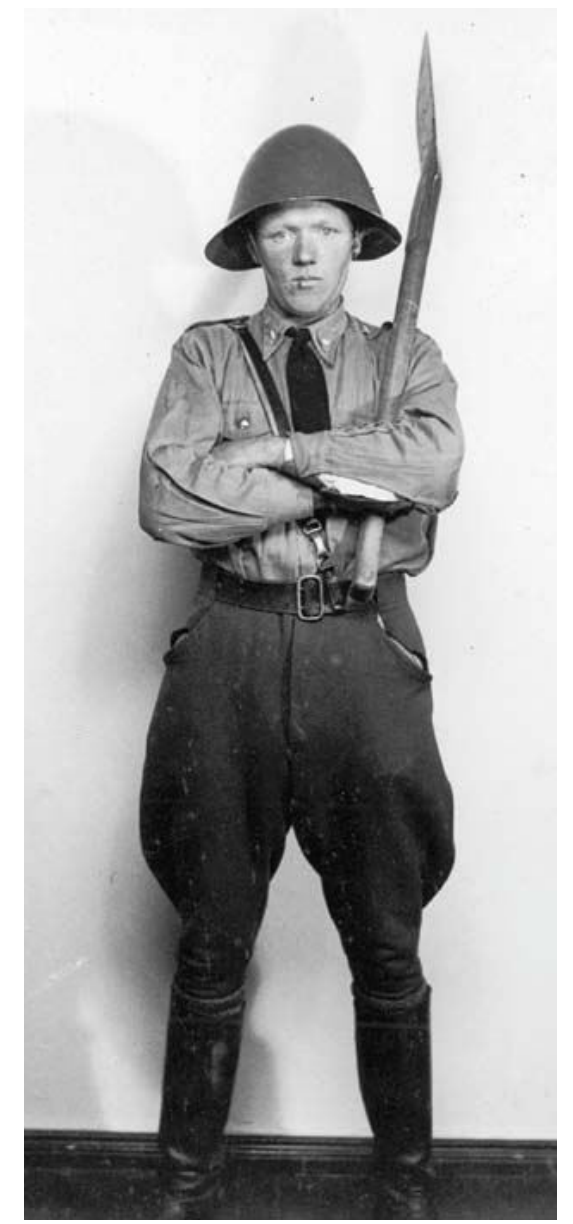

Efter anholdelserne tog politiet fotos for Efter anholdelserne tog politiet fotos for buddet. Her ses en mellemfornøjet $S A$ sektionsfører $i$ opstilling som spadevagt. Foto: Rigsarkivet Aabenraa, Haderslev politi nr. 909 . 
overhovedet anvendte tåregas. Efter rigspolitichefens instruks måtte tåregas kun anvendes i nødværge. Det er diskutabelt, om der forelå en nødværgesituation i forbindelse med anholdelserne, og brugen af brandsprøjter var slet ikke nævnt i instruksen. Indsættelsen af begge magtmidler var imidlertid nødvendig for at gennemføre anholdelserne uden at et større antal politifolk skulle såres hårdt ved spadehug. Tåregassen, og særlig brandsprøjterne, var desuden mildere magtmidler end knipler, endsige pistoler. Med sin på én gang resolutte og afpassede reaktion forhindrede politiet dels, at Spadeslaget blev startskuddet til en oprørslignende tilstand fremkaldt af SA, dels at SA fik sine martyrer - to situationer, som hver især måske kunne have provokeret besættelsesmagten til at gribe ind. Samlet må politiets indsats i Spadeslaget bedømmes som konsekvent, kontant, koordineret og konduitepræget, om end måske ikke i alle detaljer korrekt i henhold til instrukserne. I december 1940 havde Danmark således et politi, som var rede til at hævde loven til forsvar for det demokrati, der var tilbage efter den 9. april.

Opløbet efter SA-folkenes løsladelse og overgrebene mod dem var uværdige, men faldt tilbage på uromagerne. Politiet forholdt sig ikke passivt, men dets ressourcer var utilstrækkelige.

Spadeslaget afspejlede den særlige danske besættelsessituation med en intakt dansk regering og en dansk-tysk samarbejdspolitik. Mens den tyske kommandant i Haderslev i overensstemmelse med den tidligere indgåede aftale med de danske myndigheder holdt sine soldater på afstand fra konfrontationen mellem DNSAP og politiet, hvilket var altafgørende for Spadeslagets forløb, intervenerede det tyske gesandtskab senere og med held for en fuld amnesti til SA'erne. For besættelsesmagten var det vigtigt, at arrangementet med den danske regering fra den 9. april $1940 \mathrm{ikke}$ blev underløbet af DNSAP, mens det ikke kostede den noget at vise solidaritet med de danske nazister bagefter.

For DNSAP blev Spadeslaget endnu en offentlig fiasko, som yderligere øgede partiets afstand fra regeringsmagten. Forsøgene på at opnå denne via demonstrationer på gader og stræder blev indstillet. Heri ligger Spadeslagets Danmarkshistoriske betydning.

For Sønderjyllands danske og demokratiske flertalsbefolkning samt for antinazistisk indstillede over hele landet var det nederlag, som Spadeslaget var for de danske nazister, en tiltrængt opmuntring i en mørk tid.

\section{KILDER}

Utrykte kilder:

Rigsarkivet Aabenraa (RAÅ):

Haderslev politi nr. 908-913, udtaget journalsag 2458 vedr. Spadeslaget, heri bl.a.:

Politimester Hartmanns rapport 28.12.1940 (i nr. 911) med følgende bilag:

Politiassistent C.J. Tofts rapport 8.12.1940 (nr. 910)

Rids af Højskolehjemmet med politiets opstilling (nr. 911)

Fotoalbum (nr. 909)

Liste over tilskadekomne politifolk (nr. 911) Erklæring fra kredslægen om sårede SA'ere (nr. 910)

Overbetjent M. Riis' rapport om det of fentlige møde 11.12.1940 (nr. 911)

Sammes rapport om SA-optogets samling,
opstilling og march 27.12.1940 (nr. 910) SA's trykte organisationsbestemmelse (nr. 911)

Områdebefaling nr. 18 fra SA i område 1 , dateret Rødekro 30.11.1940 (nr. 911)

Kolonnebefaling nr. 1 fra SA 4. kolonne, dateret Tinglev 30.11.1940 (nr. 911)

Overbetjent Riis' rapport 27.12.1940 med resumé af de fundne effekter, dvs. bilag 8-10 og 12 (nr. 910)

Nøgle til koden i områdebefalingen (nr. 911)

\section{LITTERATUR}

Billeschou Christiansen, Søren og Hyllested, Rasmus: På den forkerte side. De danske landssvigere efter befrielsen. Aarhus 2011.

Koch, Henning: Demokrati slå til! Statslig nødret, ordenspoliti of frihedsrettigheder 1932-1945. København 1994.

Lauridsen, John T.: Dansk nazisme 1940-45 - og derefter. København 2002.

Poulsen, Henning: Besxttelsesmagten og de danske nazister. Det politiske forhold mellem tyske myndigheder og nazistiske kredse i Danmark 1940-43. København 1970.
Afhøringsrapporter 8. og 12.12.1940 med Jes Friis' forklaring og 8.-9.12.1940 med Jes Asmussens (nr. 910)

Rapporter 10.1. og 10.2.1941 om afhøring af 18 betjente, som deltog i Spadeslaget (nr. 911)

Politiadjudantens arkiv nr. 200, journalsag 6221.

Rigsarkivet København (RAK):

Udenrigsministeriets arkiv nr. 120-13: Gruppeordnede sager 1909-1945 120.D.18.d., Haderslev-Affæren 8/1240 og Amnesti og Benaadning af danske Nationalsocialister

Trykte kilder:

Alkil, Niels (red.): Besættelsestidens Fakta. København 1945, bd. I.

Fædrelandet 1940.

Lauridsen, John T. (udg.): Føreren har ordet! Frits Clausen om sig selv og DNSAP. København 2003.

Lovtidende for Kongeriget Danmark for 1940. København 1940.

Nordschleswigsche Zeitung 1940.
Poulsen, Henning: Besættelsesårene 19401945. Aarhus 2002.

Rasmussen, René: "De danske nazister". Hans Schultz Hansen og Henrik Skov Kristensen (red.): Sønderiylland under krig og besxttelse 1940-1945. Aabenraa 2003, s. 77-93. 


\section{NOTER}

1 Poulsen 1970, især s. 59-245 samt konklusion s. 385-391 og resumé s. 484-489.

2 Koch 1994.

3 Koch 1994, s. 80f, 163-165, 218-221. Afskrift af politibekendtgørelse om møde- og demonstrationsforbud i de sønderyyske politikredse af 12.4.1940 i RAÅ, Haderslev politi nr. 911.

4 Lovtidende for Kongeriget Danmark Lovtidende for Kongeriget Dan
for 1940 . København 1940, s. $277 f$.

5 Koch 1994, s. 204-211. Poulsen 1970, s. 164-167.

6 Koch 1994, s. 211-213. Poulsen 1970, s. $170 \mathrm{f}$.

7 Koch 1994, s. 215. Lovtidende 1940 s. 1673.

8 Koch 1994, s. 216-218. Poulsen 1970, s. 222-226.

9 Poulsen 1970, s. 233

10 Poulsen 1970, s. $232 \mathrm{f}$

11 Koch 1994, s. 221-227.

12 Om DNSAP i Sønderjylland, se Rasmussen 2003. Se også Lauridsen 2002 bl.a. med DNSAP-leksikon s. 473-555 og fortegnelse over sysler og sysselledere s. 568-571.

13 Om SA generelt og i Sønderjylland, se Alkil 1945, bind I, s. 431-444 samt Lauridsen 2002, s. 476, 494, 509, 537f, 571.

14 RAÅ, Haderslev politi nr. 911, bilag 8 til Hartmanns rapport 28.12.1940.

15 RAÅ, Haderslev politi nr. nr. 910, afhøring af Jes Friis 8.12.1940, og samme nr. 911, Hartmanns rapport 28.12.1940, s. 1

16 Koch 6.

17 RAÅ, Haderslev politi nr. 910, Tofts 7 RAA, Hadersle

18 Samme s.

19 Samme s. 3.

20 RAÅ, Haderslev politi nr. 208, rappor af 16.12 .1940$.

21 RA ̊, Politiadjudantens arkiv nr. 200 journalsag 6221. Afskrift.

22 RAÅ, Haderslev politi nr. 910, rapporter af 9.12. og 30.12.1940.

23 RAÅ, Haderslev politi nr. 911, Hartmanns rapport 28.12 .1940$, s. 3 .

24 Koch 1994, s. 136, 150-155, 193 f.

25 Koch 1994, s. 216.
26 RAÅ, Haderslev politi nr. 911, udklip af annonce i Fædrelandet 6.12.1940. Der er her en underordnet uoverensptemme mert Hartmanns rapport 28.12.1940 s. 1 og Tofts rapport 8.12 .1940 s. 2, idet førstnæunte anføre at posten ved Højskolehjemmet kl. 15 skulle udvides med to mand, sidstnavnte, at posten skulle udvides til to mand. Her følges Tofts samtidige rapport.

27 RAÅ, Haderslev politi nr. 911, bilag 9-10 og 12 til Hartmanns rapport. Samme nr. 910, bilag 11.

28 RAÅ, Haderslev politi nr. 910, afhøring af Jes Friis 12.12.1940

29 RAÅ, Haderslev politi nr. 910, afhøring af Jes Asmussen 8.-9.12.1940.

30 Jes Friis' privatarkiv, der netop er afleveret til Rigsarkivet i Aabenraa, ha ikke kunnet kaste lys over, hvorvid Frits Clausen var involveret i beslutningen om marchen og mødet.

31 RAÄ, Haderslev politi nr. 910, rapport ved overbetjent M. Riis 27.12.1940.

32 RAÅ, Haderslev politi nr. 910, afhøring af Jes Friis 8.12.1940 og Asmussen 8. 9.12.1940.

33 Cirkulæret i RAÅ, Haderslev politi nr. 910.

34 Poulsen 1970, s. 59f, 232

35 RAÅ, Haderslev politi nr. 910, afhøring af Jes Friis 8.12.1940. Se også RAA, Haderslev politi nr. 911, bilag 6 til Hartmanns rapport ved overbetjent M. Riis, s. 2, hvorefter spaderne var stillet op "et sted i hjørnet mellem cykelskuret og brænderummet ved bilgaragerne øst for indgangen til forstue og salen". 36 RAÅ, Politiadjudantens arkiv nr. 200 journalsag 6221

37 RAÅ, Haderslev politi nr. 911, Hartmanns rapport 28.12.1940 s. 7.

38 RAÅ, Haderslev politi nr. 910, afhøring af Jes Friis 12.12.1940

39 RAÅ, Haderslev politi nr. 911, bilag 6 til Hartmanns rapport ved overbetjent M. Riis, s. 2.

40 RÅ̊, Haderslev Politi nr. 911, rapport af 10.1.1941, udsagn ved politibetjent Christian Bruun.
41 RAÅ, Haderslev Politi nr. 911, rapport af 10.1.1941, udsagn ved politibetjentene C.M. Petersen, H. Riber Bertelsen Ove Jacobsen, Chr. Skovby, Nikolaj Asmussen.

42 RAÅ, Haderslev Politi nr. 911, rappor af 10.1.1941, udsagn ved politibetjent Christian Bruun

43 RAÅ, Haderslev Politi nr. 911, rapport af 10.1.1941, udsagn ved politibetjent Christian Holm

44 RAÅ, Haderslev Politi nr. 911, rapport af 10.1.1941, udsagn ved politibetjent Nikolaj Asmussen

45 RAÅ, Haderslev Politi nr. 908, afhøring af kriminalbetient Svend Mathiesen 11.12.1940. Sst. nr. 911, rapport a 10.1.1941, udsagn ved politibetjent C.M. Petersen, Mads Ravn, Ove Jacobsen.

46 Hartmanns rapport 28.12. s. 5: "ca. 150 mand foruden kriminalpolitiet", Tofts rapport 8.12 kr "Ordet, lofts

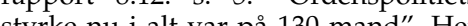
følges Tofts samtidige og mere præcise følges To ts

47 RÅ, Haderslev politi nr. 911, bilag 6 RAA, Haderslev politi nr. 911, bilag 6
til Hartmanns rapport ved overbetjent M. Riis 11.12.1940.

48 RAÅ, Haderslev Politi nr. 908, afhøring af Lærum 12.2.1941 bilagt manuskrip samt afhøring af Riis 25.2.1941 og a Nielsen 1.3.1941

49 RAÅ, Haderslev politi nr. 910, afhøringer af Jes Friis 8.12. og 12.12.1940.

50 RAÅ, Haderslev Politi nr. 911, rappor af 10.1.1941, udsagn ved politibetjen Hans Hybschmann.

51 RAÅ, Haderslev Politi nr. 911, rapport af 10.1.1941, udsagn ved politibetjent Hans Hybschmann. Jfr. nr. 908, rapport 8.12.1940 ved kriminalbetient Johannsen, der nævner, at Frits Clausen ca. kl. 20.30 indfandt sig på politistationen.
52 RAÅ, Politiadjudantens arkiv nr. 200, journalsag 6221, rapport 11.12.1940. 53 RAÅ, Haderslev politi nr. 911, bilag 4

54 RAÅ, Haderslev politi nr. 910, bilag 5 til Hartmanns rapport ved kredslæge Lauritzen.

55 Fædrelandet 14.12.1940, gengivet i Alkil 1945 , bind I, s. 444-446. Udklip af Fædrelandet 9., 10. og 14.12.1940 i RAÅ, Haderslev politi nr. 911

56 RAÅ Haderslev politi nr. 908, rapport af 16.12.1940.

57 Nordschleswigsche Zeitung 10.12.1940.

58 RAÅ, Haderslev Politi nr. 910, Hartmanns rapport af 28.12.1940 samt nr. 908, A.N. Jensens rapport 22.12.1940.

59 RAÅ, Haderslev Politi nr. 910, rapport af 22.1.1940.

60 Gengivet i dansk oversættelse hos Lauridsen 2003, s. 688-691. Jfr. Poulsen 1970, s. 234.

61 Poulsen 1970, s. 235-238.

62 Om de dansk-tyske forhandlinger om amnesti, se RAK, Udenrigsministeriets arkiv nr. 120-13.

63 RAA, Haderslev Politi nr. 911, fortegnelse over deltagere $i$ optoget og mødet på Højskolehjemmet i Haderslev den 8. december 1940 med angivelse af de rejste sigtelser, dateret 24.9.1945. Listen omfattede 218 personer.

64 Koch 1994, s. 228

65 Billeschou Christiansen og Hyllested 2011, s. 246.

66 RAÅ, Haderslev Politi nr. 908, Hartmanns indstilling 21.3.1941 og rigspolitichefens brev af 16.4.1940, jfr. RÅ Haderslev Politi nr. 911, bilag 4 til Hartmanns hovedrapport. Se også Koch 1994, s. 238f.

67 Poulsen 2002, s. 51. 


\section{Zusammenfassung}

Am 8. Dezember 1940 veranstaltete Dänemarks National-Sozialistische Arbeiter-Partei eine öffentliche Kundgebung im ,Højskolehjemmet' in Hadersleben. Vor der Kundgebung marschierten ungefähr 275 Mann von der schleswigschen 'Sportsabteilung' der DNSAP in Uniform und mit Spaten bewaffnet durch die Stadt. Damit verstieß die SA bewuss gegen das Verbot der politischen Uniformierung. Die Polizei in Hadersleben konnte alleine den Marsch nicht verhindern. Mit Verstärkung aus den benachbarten Polizeikreisen wurde aber das ,Højskolehjem' umstellt. Es kam zu Schlägereien, als die Polizei zwei Wachtposten der SA verhaftete. Mehrere Polizisten wurden durch Spatenschläge verletzt, den Polizeibeamten wurde befohlen, ihre Waffen zu ziehen, jedoch kam es nicht zum Schießbefehl. Nach der Kundgebung verließen die Zivilisten den Saal. Mitglieder der SA weigerten sich verhaftet zu werden und blieben im Saal. Mittlerweile war die Zahl der Polizeibeamten auf 130 angestiegen. Die Mitglieder der SA wurden unter Anwendung von Tränengas heraus getrieben. Mit ihren Spaten versuchten die SAMitglieder die Polizeisperre zu durchbrechen, wurden aber mit kalten Wasserstrahlen von Brandspritzen zur Ruhe gebracht. Insgesamt 239 wurden verhaftet. 23 Polizeibeamte und 10 SA-Mitglieder wurden verletzt bei den Zusammenstößen, die im Volksmund als "Spatenschlacht" bezeichnet wurde. Die Spatenschlacht war für die DNSAP eine Niederlage. Die Wehrmacht hielt sich von den Auseinandersetzungen fern.

\section{Side om side i det kommende Europa}

\author{
København-Bonn erklæringerne \\ og Vesttysklands optagelse i NATO, 1948-1955
}

Af Jesper Thestrup Henriksen ${ }^{1}$

Fremstillingen af Vesttysklands optagelse i NATO har i Danmark ofte været knyttet til en løsning af mindretalsspørgsmålet i Sydslesvig som et dansk krav til tyskerne, inden man ville godkende deres NATO-medlemskab. Og fokus har ofte været rettet mod den danske regerings og andre danske politikeres indsats i den anledning. I denne artikel argumenteres for, at der var fælles danskvesttyske sikkerhedspolitiske interesser i et tæet forsvarssamarbejde mellem de to lande, der gjorde det oplagt at løse mindretalsproblemerne nord og syd for grænsen samtidig med Vesttysklands optagelse i NATO. Interesser, der navnlig blev varetaget af konservative danske og tyske parlamentarikere i forberedende samtaler forud for det afgørende NATO-topmøde i Paris.

\section{Indledning}

Den 29. marts 1955 underskrev den danske stats- og udenrigsminister H.C. Hansen og den vesttyske forbundskansler Konrad Adenauer hver deres ensidige erklæring. Erklæringerne skulle for fremtiden sikre henholdsvis det tyske og det danske mindretals politiske og kulturelle rettigheder. De to erklæringer er siden blevet kendt som København-Bonn erklæringerne, og de er efterfølgende blevet tillagt stor betydning for en ny begyndelse for mindretallene, ligesom de er blevet fremhævet som en model for lignende mindretalsløsninger andre steder i Europa. ${ }^{2}$ Erklæringerne er ligeledes blevet tillagt stor betydning for forholdet mellem Danmark og Vesttyskland, herunder især for samarbejdet inden for NATO.

I denne artikel bliver København-Bonn erklæringerne primært vurderet ud fra et sikkerhedspolitisk perspektiv. Der argumenteres for, at erklæringernes tilblivelse i høj grad hang sammen med den sikkerhedspolitiske situation i midten af 1950'erne. I forlængelse heraf bliver det påvist, at det var utænkeligt, at den danske regering havde nedlagt veto mod et tysk NATO-medlemskab, hvis ikke der var fundet en løsning på det danske mindretals problemer i Sydslesvig. Dette syn adskiller sig 